\title{
Exhumed fault scarps and drainage modification as proxies of neotectonics at the Abu Dabbab area, Eastern Desert, Egypt
}

\author{
Ahmed Akawy \\ Geology Department, Faculty of Science, \\ South Valley University, Qena, Egypt
}

\begin{abstract}
The basement rocks, Neogene sediments and Quaternary alluvial deposits in the Abu Dabbab area, Eastern Desert of Egypt, are deformed by N-S, NE-SW, NW-SE and E-W trending faults. Complex cross-cutting relationships show a complicated history of initiation and reactivation of these faults. The recent fault scarps demonstrate different morphologies, modes of formation and relative ages. Recurrent, step and successively reactivated faulting was likely responsible for the exhumation and neo-formation of the fault scarps. Capture, deep incision, offset and reversal in flow direction of streams are the main drainage modifications induced by active faults. The concealed and active faults are associated with high drainage density anomalies. Segmentation phenomenon is common for all fault trends. Microearthquakes are concentrated at the intersection zones of faults and caused by upper crustal strike-slip, oblique-slip, reverse and normal faults. The paleostresses are not consisten with the present-day stress fields. The present-day NE-SW extension across the Red Sea combined with a local multidirectional tension led to reactivation of old faults and initiation of new fault trends.
\end{abstract}

Key words: fault scarps, active faults, drainage, tectonic geomorphology, Abu Dabbab, Egypt

\section{Introduction}

Several localities of active tectonics were identified in the Eastern Desert of Egypt and Nile Valley, i.e. the Qena-Safaja stretch (El Kazzaz 1999; Akawy 2002), the Nile bend at Qena and surroundings (Akawy and Kamal El Din 2006), the Umm Gheig area (Akawy 2005) and the Kalabsha fault zone, southwest Aswan. There is a variation in character of the active tectonics from one locality to the other. It is represented by active fissures, tilting of Quaternary beds, deflection in

Address: A. Akawy: Geology Department, Faculty of Science, South Valley University, Qena, Egypt, e-mail: ahmakawy@yahoo.com.

Received: March 20, 2008; accepted: May 31, 2008 
drainage patterns and/or reactivation and exhumation of old faults. To build a general model for active tectonics in the Eastern Desert, several areas should be studied.

The Abu Dabbab area is located on the western margin of the Red Sea, to the northwest of Marsa Alam (Fig. 1). Historically, the Abu Dabbab area means the area of sound tremor due to frequent falling blocks as named by the desert inhabitants (El-Gaby, personal communication). The falling block phenomenon is assigned to the effect of active tectonics.

Fault scarps are useful in analysis of active tectonics. Analysis of the scarp morphology is useful in dating faults (Nash 1980; Mayer 1984; Carretier et al. 2002). The pattern of fault scarps and accumulation of sediments are indicators of the degrees of stability and activity of the faults. The present contribution is aimed at assessment of the active tectonics in the Abu Dabbab area on basis of analyzing: 1) the fault scarps, 2) the drainage pattern modification, 3) the measured field data and 4) the recent seismic records. A general model for the present-day stress field is introduced.

\section{Geologic setting}

The study area (Fig. 1) extends from Wadi Abu Nabi as-Saghir in the south to Wadi Mubarak in the north, between latitudes $25^{\circ} 15^{\prime} 00^{\prime \prime}$ and $25^{\circ} 30^{\prime} 00^{\prime \prime}$. The Red Sea shoreline and longitude $34^{\circ} 30^{\prime} 00^{\prime \prime}$ bound the area on the east and west, respectively.

The exposed Precambrian basement rocks in the study area include metasediments, metavolcanics, serpentinite, a metagabbro-diorite complex, gabbro, and younger granitoids (Table 1). The sedimentary rocks in the study area range in age from Middle Miocene to Quaternary. The main rock units are the Gabal El Russas Formation, the Gypsum Formation, the Marsa Alam Formation, the Shagara Formation and the Quaternary sediments.

\section{Field investigation on faults}

The study area is dissected by different faults and fractures in the N-S, NE-SW, NNW-SSE, NW-SE and E-W directions (Fig. 2). Adjacent to the study area there is an irregularity in the Red Sea shoreline. The latter may be attributed to fault and fracture intersection. Displacement of sedimentary units and offset of drainage lines are the main displacement criteria across the faults.

\section{N-S faults}

Although the N-S faults have moderate frequency relative to the occurrence of other fault orientations, they extend for long distances. Over the entire study area, these faults occur either as individual fault planes or fault zones of varying 
widths. In the extreme southwestern corner of the study area a N-S shear zone can be traced over several kilometers. On mesoscopic scale, these faults show zoning, splaying and interlinking. A small number of the inspected fault planes show horizontal slickolites implying a strike-slip component. Superimposed right and left senses of movement were recorded along the N-S faults, indicating younger left-lateral movement. Within the basement rocks the sense of

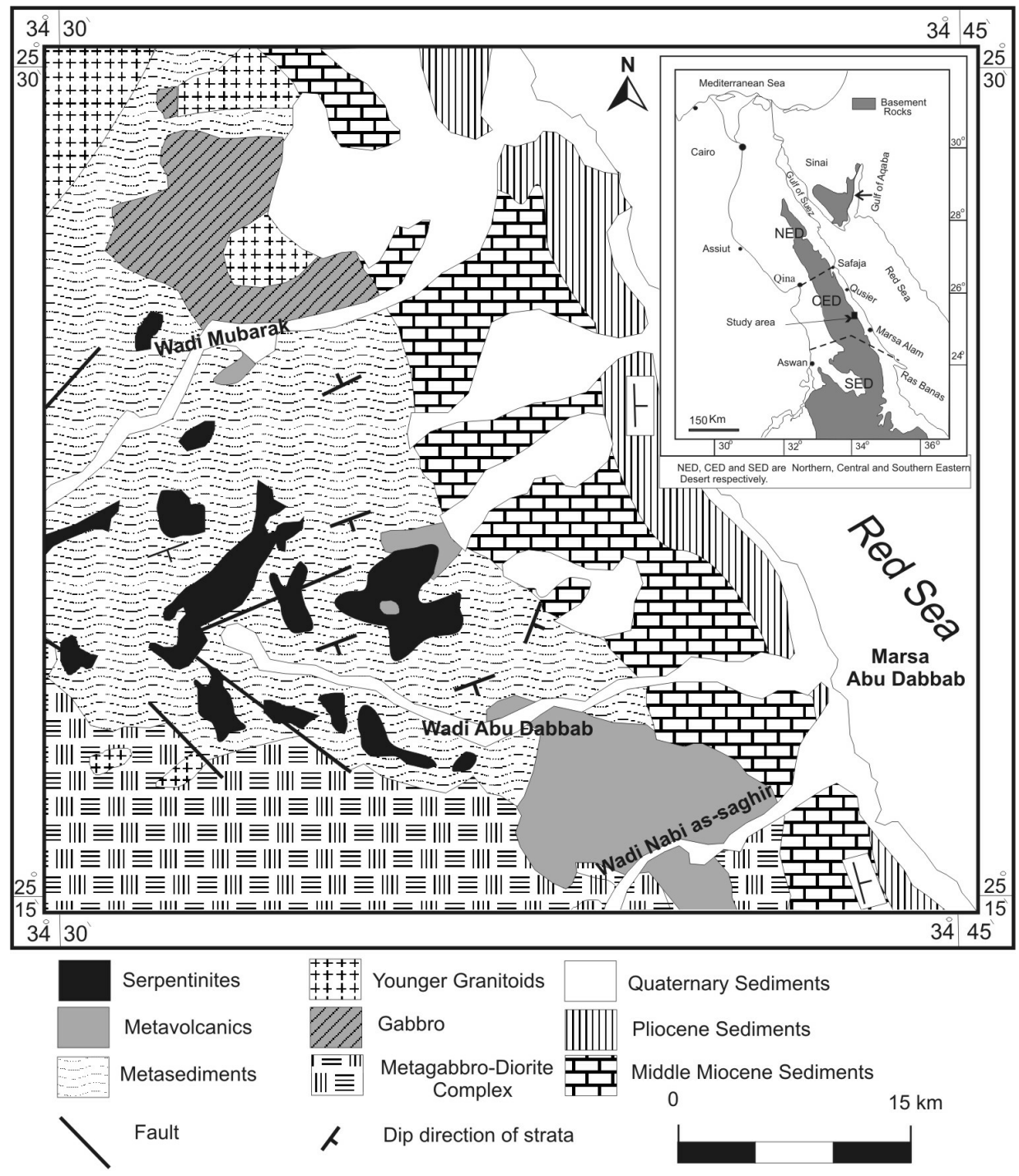

Fig. 1

Geologic map of Abu Dabbab area (after the Geological Survey of Egypt, 1979). The inset is a location map 
Table 1

Rock units in the study area

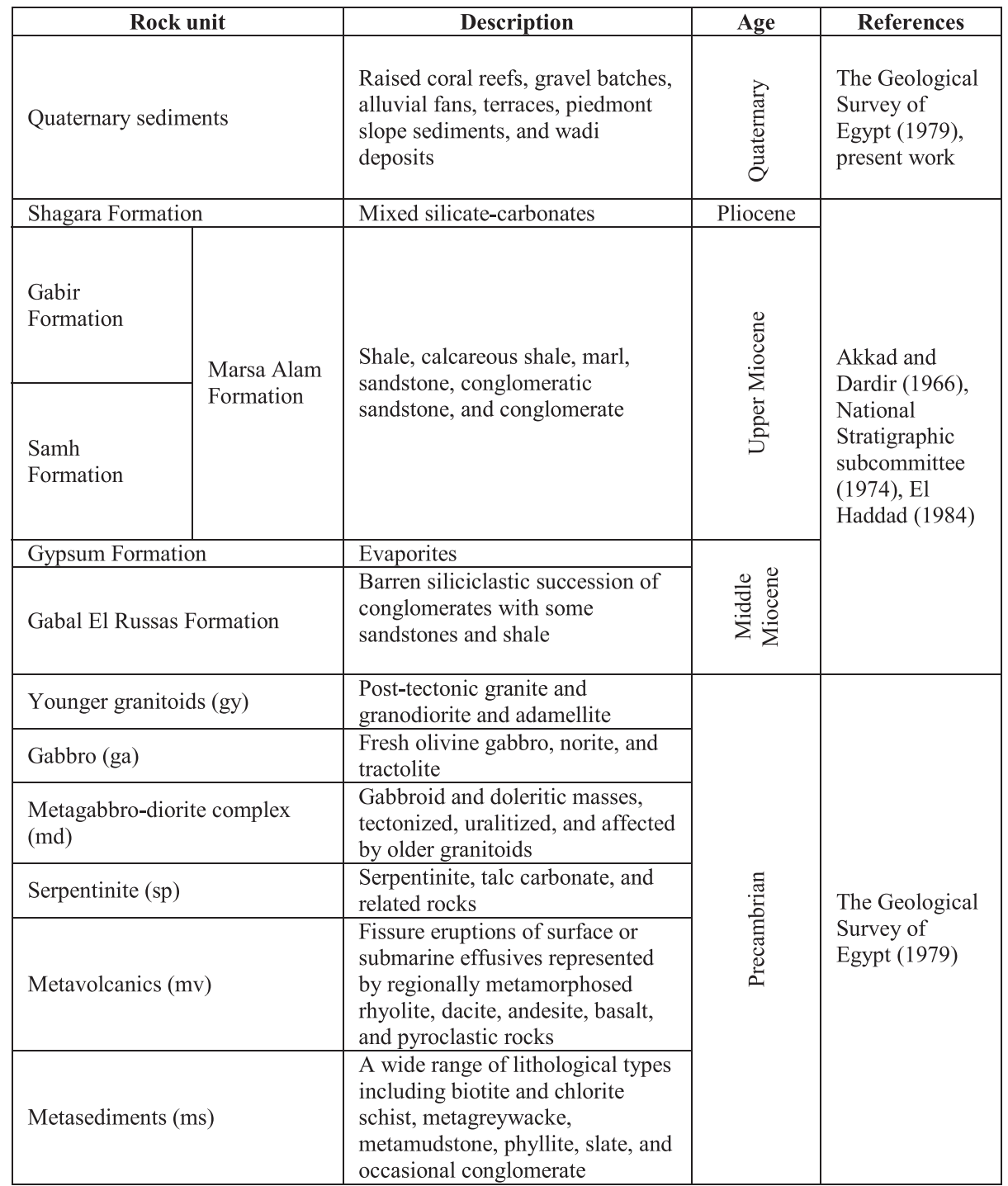

movement is inferred from the direct offset of markers, i.e. tailed porphyroclasts and direction of roughness and smoothness on fault surfaces. Some N-S faults are highly oblique to normal with steep plunging slip lineation (Fig. 3A). Thanks to the competency of the country rocks, rare asymmetric minor folds were recognized. On aerial photographs the $\mathrm{N}-\mathrm{S}$ trending faults are associated with sharp-crested, steeply dipping ridges. Along the $\mathrm{N}-\mathrm{S}$ faults there is a variation in 


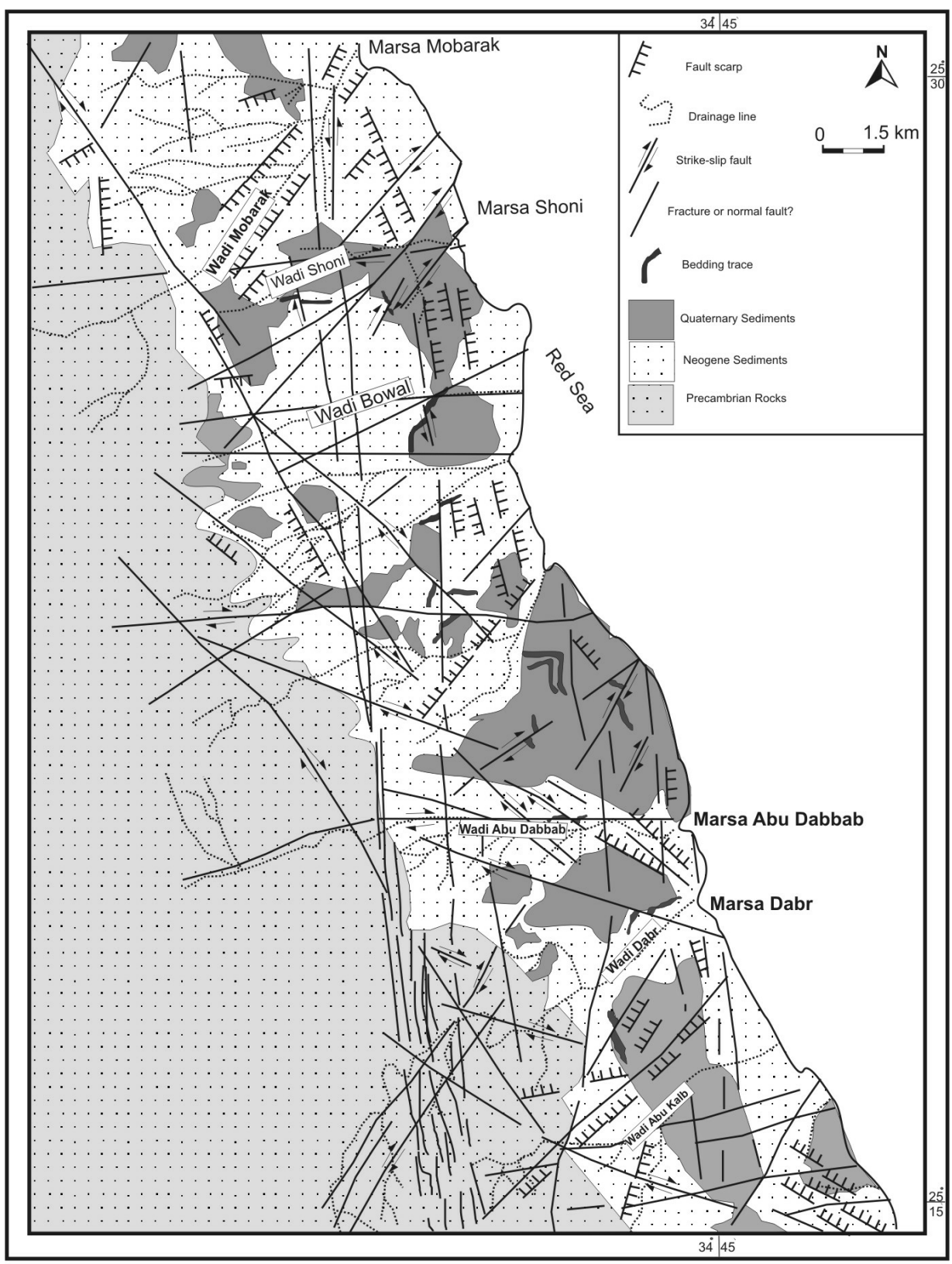

Fig. 2

Structural-shape map of the Abu Dabbab area (based on photomosaic 1:50,000) 
displacement amount from one fault to the other (Akawy 2007). The displacement ranges from several centimeters to several kilometers. Some N-S fractures are open and barren, implying recent activation (Fig. 3B). The Miocene rocks and the overlying Quaternary sediments are highly deformed by N-S normal faults. This deformation is represented by steep tilting and clay injection of soft sedimentary rocks (Fig. 3C).

\section{NE-SW faults}

In the Precambrian basement rocks, NE-SW right-lateral strike-slip faults were recorded; they were reactivated during later times as normal faults (Fig. 3D). Superimposed slip lineations were recorded. NE-SW extensional barren fractures cut the basement and Neogene rocks and their overlying Quaternary sediments (Fig. 3E and F). The basement rocks adjacent to the sediments show a rough surface due to frequent opening of the NE-SW extension fractures. The NE-SW faults share with other trends in controlling the course of drainage lines toward the Red Sea. The drainage lines that are controlled by the NE faults and fractures are generally asymmetrical as represented by a steep side of the valley (Fig. 3G) whereas the other side is gentle.

\section{NW-SE faults}

The NW-SE faults are well developed in the study area and the frequency increases westward in the basement rocks. The old generation of this fault trend consists of left-lateral strike-slip faults that have also been reactivated in later times as normal faults. The strike-slip and normal faults cut the entire rock sequence, from basement rocks to Quaternary sediments. In addition to the direct offset of the Neogene and Quaternary sediments, several highly tilted and dragged beds near the NW-SE faults were recorded (Fig. $3 \mathrm{H}$ ).

\section{E-W faults}

Most of the E-W faults extend, with some interruption, from the Red Sea shoreline westward and cut through all lithologies. Although the mapped E-W faults run over long distances, their frequency is low. The field work clarified that these faults swing over $15-20^{\circ}$ around the main azimuth direction and show deformation exceeding that of the other fault trends. Different fault types and a

Fig. $3 \rightarrow$

Field photographs of the structural features of the faults. A) Steeply plunging slip lineation on a N-S fault plane; B) Open, barren N-S fracture; C) Highly tilted mélange of Neogene rocks (covered by Quaternary sediments) deformed by the N-S fault;. D) Steeply plunging slip lineation on a NE-SW fault plane; E-F) Open, recent NE-SW fractures affecting basement and Neogene rocks, respectively; G) Steep side of drainage valley due to the NE-SW faults; H) Neogene beds overlying basement rocks are tilted and dragged by the effect of the NW-SE faults 

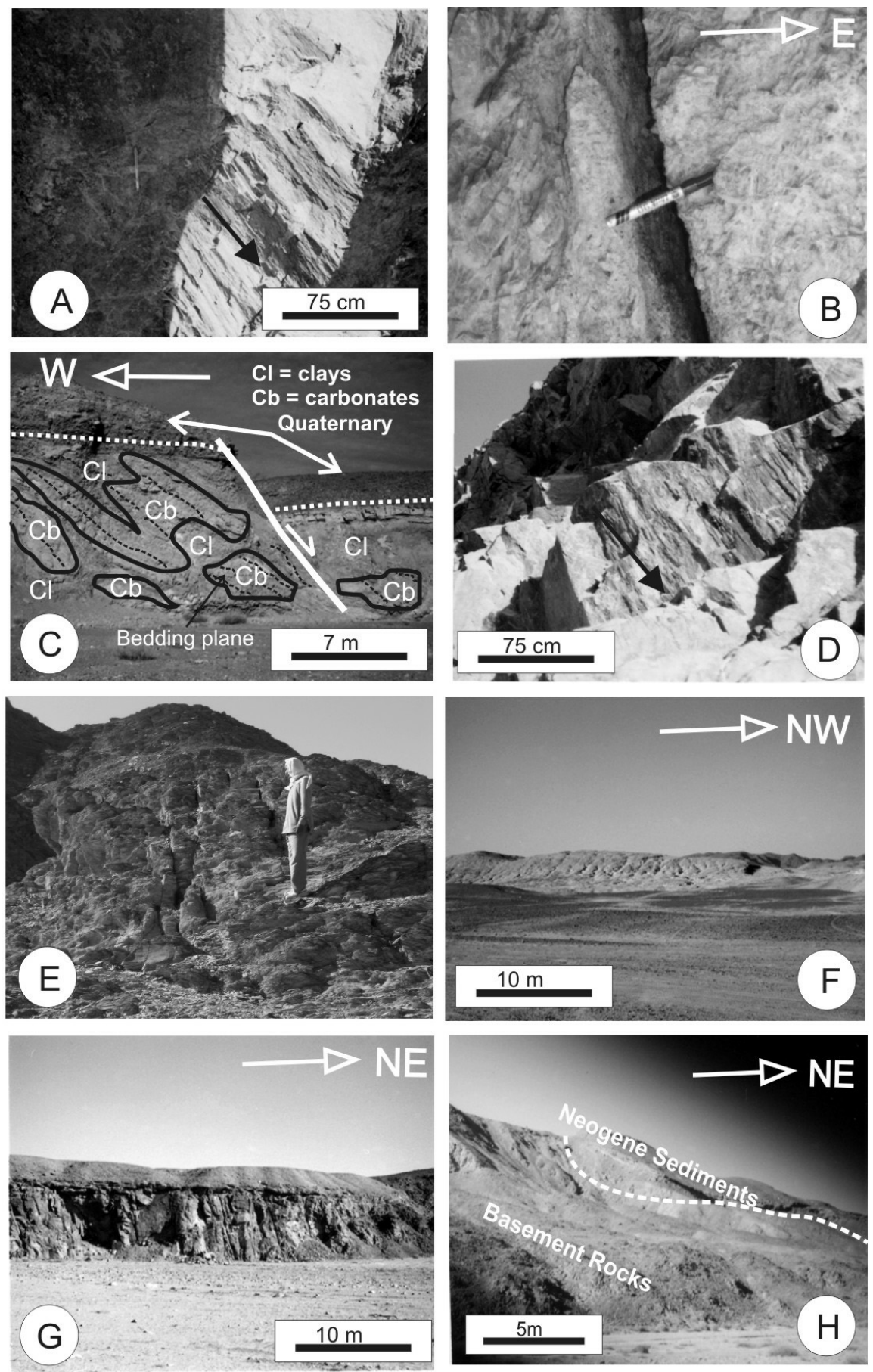

Central European Geology 51, 2008 

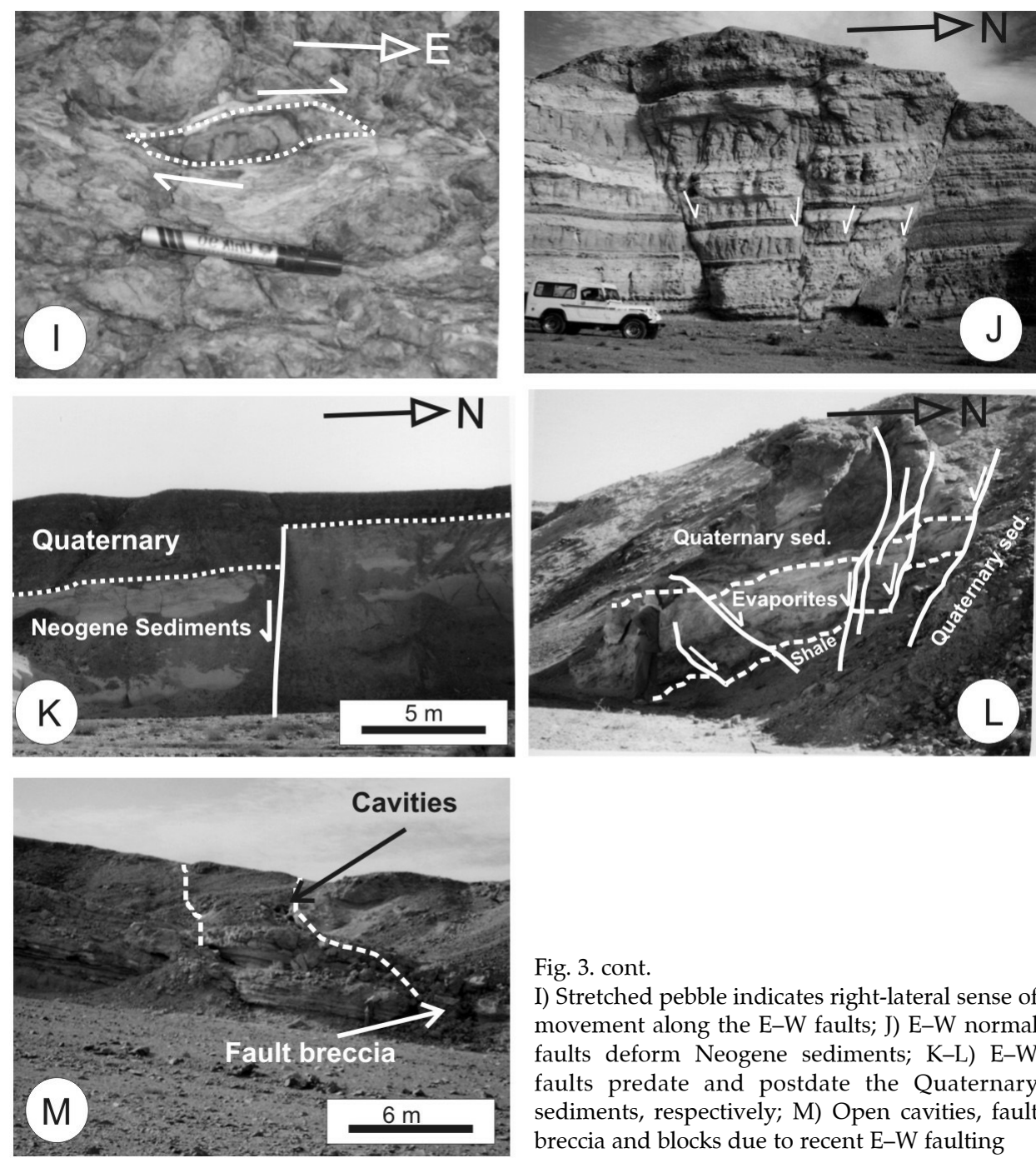

Fig. 3. cont.

I) Stretched pebble indicates right-lateral sense of movement along the E-W faults; J) E-W normal faults deform Neogene sediments; K-L) E-W faults predate and postdate the Quaternary sediments, respectively; M) Open cavities, fault breccia and blocks due to recent $\mathrm{E}-\mathrm{W}$ faulting

history of multiple reactivation characterize the E-W faults. An old right-lateral strike-slip movement, overprinted by an oblique one, is observed in the basement rocks. The right-lateral sense of movement was deduced from several shear criteria like the tails of stretched pebbles (Fig. 3I). Normal and oblique-slip faults are common in the Neogene and Quaternary sediments (Fig. 3J). The field study showed that some E-W normal faults predate the Quaternary, whereas others postdate it (Fig. 3K and L). The majority of the E-W normal faults show mesoscopic-scale grabens, recent fault breccia, small faulted blocks and open fractures due to recent activation (Fig. 3M).

Stereographic projection of faults in all orientations is shown by Fig. $4 \mathrm{~A}$. 

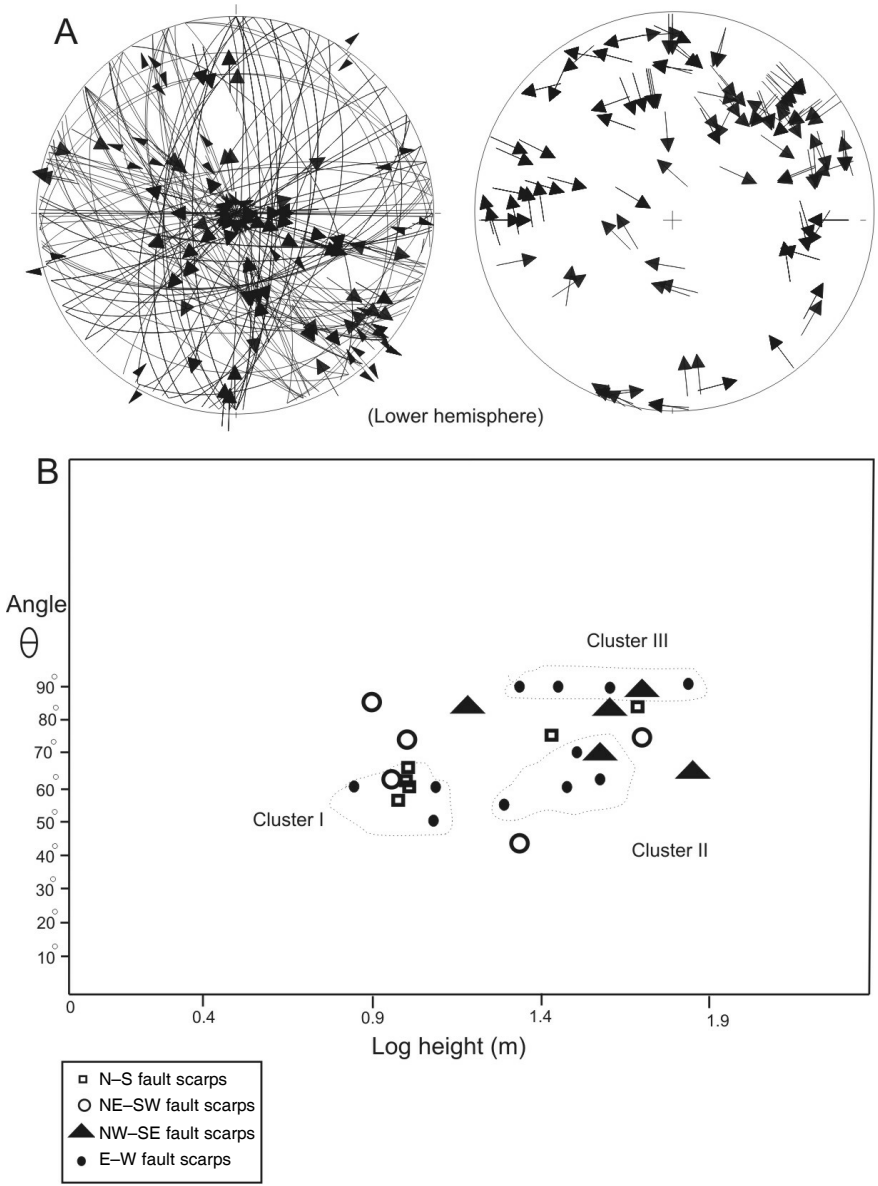

Fig. 4

Stereographic projection of fault planes and striae (A) and morphometric analysis of fault scarps (B) (after Mayer 1984)

\section{Fault scarps}

Convexity and concavity of the scarp slope indicate the relative effect of erosion and sedimentation. According to Mayer (1984), Sterr (1985) and Mayer and Vincent (1999), the relative ages of fault scarps can be inferred from the scarp profiles with the following parameters: 1) maximum slope angle, 2) scarp height, 3) position of the crest and 4) curvature of the crest.

In the study area, the anomalous elevation and sharp steepness enable recognition and tracing of fault scarps on aerial photographs (Fig. 2). The morphometry of twenty-seven fault scarps within Quaternary sediments were examined and measured (Table 2). The measured morphometric parameters 
Table 2

Morphometry of fault scarps in the Quaternary sediments

\begin{tabular}{|c|c|c|c|c|c|}
\hline Orientation & $\theta$ & $\begin{array}{c}\text { Scarp height } \\
\text { (m) }\end{array}$ & Log height & Scarp type & Apex shape \\
\hline \multirow{6}{*}{$\mathrm{N}-\mathrm{S}$ fault scarps } & $82^{\circ}$ & 50 & 1.70 & Planar & Sharp \\
\hline & $62^{\circ}$ & 10 & 1.00 & Planar & Rounded \\
\hline & $60^{\circ}$ & 10 & 1.00 & Planar & Rounded \\
\hline & $58^{\circ}$ & 13 & 1.11 & Concave & Rounded \\
\hline & $75^{\circ}$ & 28 & 1.45 & Planar & Sharp \\
\hline & $54^{\circ}$ & 11 & 1.04 & Concave & Rounded \\
\hline \multirow{5}{*}{ NE-SW fault scarps } & $75^{\circ}$ & 50 & 1.70 & Planar & Sharp \\
\hline & $75^{\circ}$ & 10 & 1.00 & Planar & Sharp \\
\hline & $62^{\circ}$ & 9 & 0.95 & Concave & Rounded \\
\hline & $43^{\circ}$ & 22 & 1.34 & Concave & Rounded \\
\hline & $85^{\circ}$ & 8 & 0.90 & Irregular & Sharp \\
\hline \multirow{5}{*}{ NW-SE fault scarps } & $70^{\circ}$ & 36 & 1.56 & Concave & Rounded \\
\hline & $85^{\circ}$ & 15 & 1.18 & Concave & Rounded \\
\hline & $85^{\circ}$ & 40 & 1.60 & Planar & Sharp \\
\hline & $90^{\circ}$ & 50 & 1.70 & Planar & Sharp \\
\hline & $65^{\circ}$ & 70 & 1.84 & Concave & Rounded \\
\hline \multirow{11}{*}{ E-W fault scarps } & $60^{\circ}$ & 30 & 1.48 & Planar & Rounded \\
\hline & $90^{\circ}$ & 70 & 1.84 & Planar & Sharp \\
\hline & $70^{\circ}$ & 32 & 1.50 & Planar & Sharp \\
\hline & $90^{\circ}$ & 22 & 1.34 & Planar & Sharp \\
\hline & $62^{\circ}$ & 38 & 1.58 & Concave & Rounded \\
\hline & $60^{\circ}$ & 12 & 1.08 & Concave & Rounded \\
\hline & $60^{\circ}$ & 7 & 0.84 & Concave & Rounded \\
\hline & $90^{\circ}$ & 40 & 1.60 & Planar & Sharp \\
\hline & $90^{\circ}$ & 28 & 1.45 & Planar & Sharp \\
\hline & $55^{\circ}$ & 20 & 1.30 & Concave & Rounded \\
\hline & $50^{\circ}$ & 12 & 1.08 & Planar & Rounded \\
\hline
\end{tabular}

$\boldsymbol{\theta}=$ maximum slope angle of the scarp

include height (in meters), orientation and maximum slope angle (inflection point). Shape of the scarp crest, curvature of slope, and lithology were taken into consideration. The field data were treated by the discrimination method, which is one of the age determination techniques. This method is based on the morphologic discrimination between scarps of different ages (Mayer 1984). In 
this method, the maximum slope angle (?) is plotted as ordinate against log scarp height $(\mathrm{H})$ as abscissa (Fig. 4B).

The distribution of the N-S fault scarps on the graph (rectangles) preferably indicates recurrent faulting as inferred from variation in steepness and height. The N-S scarps are common within the Neogene sediments (Fig. 5A). Sharpcrested morphology of some scarps in soft and friable sediments implies that their age is Quaternary or Recent. The NE-SW fault scarps (circles, Fig. 4B) show scattering and their relative ages cannot be inferred. Several NE-SW scarps originated by recent faults were recorded (Fig. 5B). The pattern of the NW-SE fault scarps (triangles) is scattered. NW-SE scarps with round apex were recorded in the bedrock and show displacement of Quaternary sediments (Fig. $5 C)$. The E-W Quaternary fault scarps are differentiated into three groups (clusters, Fig. 4B) of different morphologies and ages. Even within the same cluster there is a variation in slope angle and/or height. The E-W scarps are developed in different lithologies in the study area. In the western part of the study area where basement rocks occur, the E-W scarps are either covered with Quaternary sediments or developed in the Quaternary sediments themselves (Fig. 5D). Eastward the E-W scarps are developed mainly in Quaternary sediments. Even within the Neogene sediments the E-W scarps seem to be of Recent age. This young age is inferred from the sharp-crested scarps that developed in the soft sediments and alluvial deposits (Fig. 5E). Exhumed fault scarps were recognized in the E-W direction (Fig. 5F). Some scarps show steps, although they are developed on nearly homogeneous soft sediments (Fig. 5G).

\section{Landforms}

Numerous hills of varying altitudes are common in the study area, leading to irregular topography. The general slope is from the southwest to the northeast with several anomalous points in between. The landforms are mainly controlled by faults rather than erosion. In basement rocks linear ridges mark fault traces whereas in sedimentary rocks a few sharp ridges mark only recent faults.

The highest elevations $(600 \mathrm{~m})$ appear in the southwestern part of the study area. Within this area there is a wide variation in elevation due to the effect of vertical faults and difference in rock resistance. The height difference between adjacent landforms attains $200 \mathrm{~m}$ or more. The landforms are rugged and include ridges and mountains. Moreover, numerous isolated hills of comparatively low altitude are observed. In the western part of the study area, some mountain fronts are sharp and dissected by abandoned drainage lines. On both sides of the mountains the slope is asymmetrical and there is a non-uniformity in the direction of gentle and steep slope. Several gorges with variable widths follow the fault zones.

In the eastern part of the study area and within the same block, the variation in height between landforms is small compared to the western part. The flat areas 

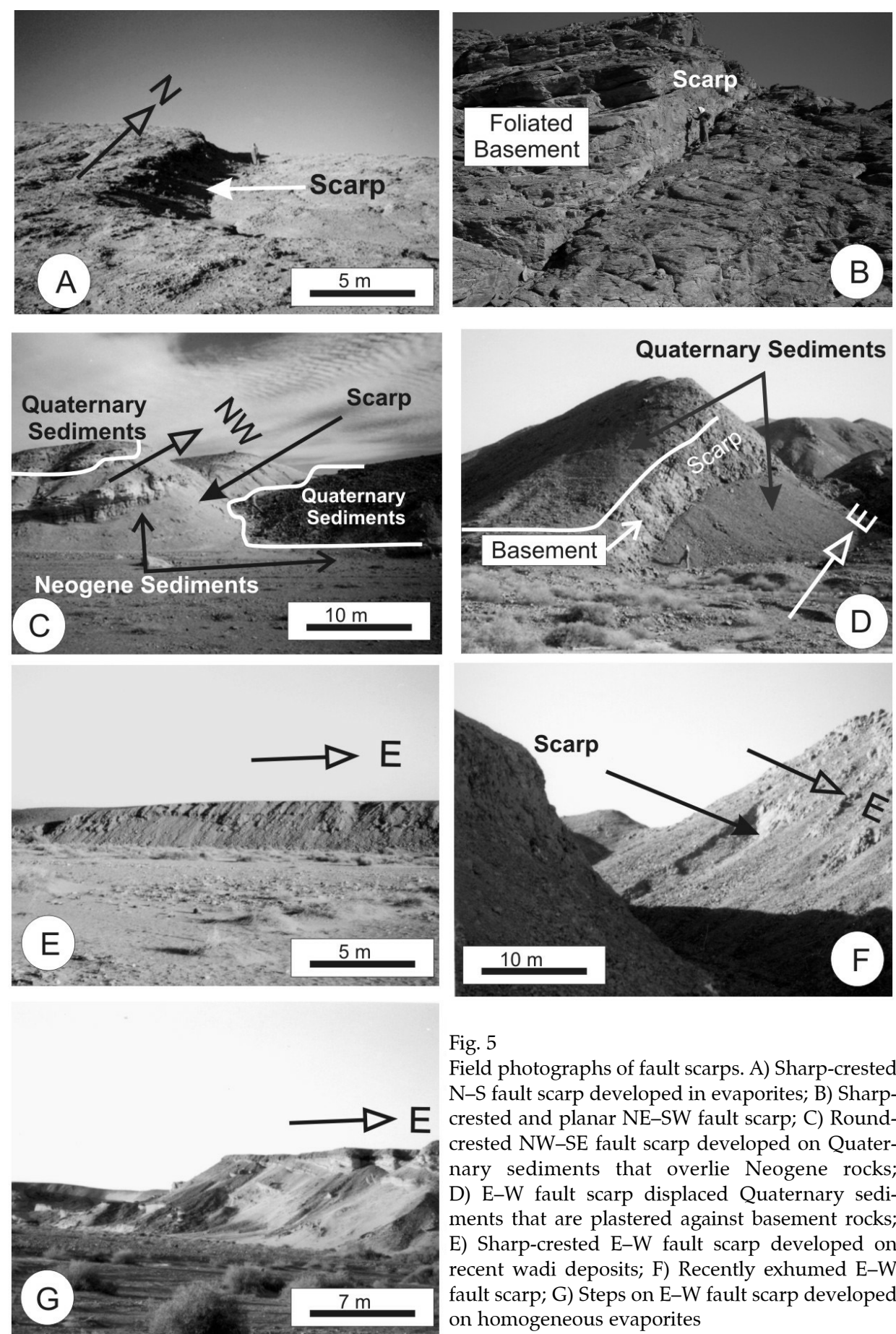

Fig. 5

Field photographs of fault scarps. A) Sharp-crested N-S fault scarp developed in evaporites; B) Sharp-

crested and planar NE-SW fault scarp; C) Roundcrested NW-SE fault scarp developed on Quaternary sediments that overlie Neogene rocks; D) E-W fault scarp displaced Quaternary sediments that are plastered against basement rocks; E) Sharp-crested E-W fault scarp developed on recent wadi deposits; F) Recently exhumed E-W fault scarp; G) Steps on E-W fault scarp developed on homogeneous evaporites 
and dissection of land by drainage lines increase eastwards while the elevation decreases to reach sea level. Isolated conical and elongated hills and small plateaus are common in the coastal area.

\section{Drainage patterns}

\section{Orientation and dimension of drainage}

The study area is crossed by a dense network of drainage lines flowing off directly toward the Red Sea basin (Fig. 6) or indirectly via the Idfu - Marsa Alam Road. The main water divide is located to the southwest of the study area and separates the valleys that drain toward the Red Sea from those draining toward the Nile Valley. In the study area local water divides appear when anomalous fault-related highs are present. The main water divide area runs with nonuniform width in a NW-SE direction while the local divides run according to the controlling faults. The height of the main water divide is about $450 \mathrm{~m}$ asl. whereas the height of local divides depends on the elevation of the hanging wall of the controlling faults.

The drainage lines run in four main trends that are NE-SW, N-S, NW-SE and $\mathrm{E}-\mathrm{W}$ as arranged in descending order of their significance (Fig. 7). The NE-SW valleys are common in the area and resemble the main drainage direction. Particularly in the eastern part of the area the NE-SW valleys represent the main part of the drainage misfit, such as Wadi Abu Wasaat and Wadi Abu Dabbab Al Abyad. The N-S valleys are concentrated in the middle and western part of the area and associated with the major N-S striking faults in the Kadabora sector. The $\mathrm{N}-\mathrm{S}$ valleys contribute to the drainage misfit in the Kadabora sector (e.g. point $\mathrm{X}$ in Fig. 6). The distribution of the NW-SE and E-W valleys is regular over all of the area. The NE-SW valleys combine with the N-S ones in capture of the NW-SE valleys and hence drainage deflection and misfit appear. The NE-SW valleys are more active and invade the other ones. Better examples of the invading and incision are point X2 in Fig. 6 (Wadi Dabr) and point X3 in Fig. 6 (Wadi Wasaat) where the NE-SW valleys join the NW-SE ones. In some localities the E-W valleys are active and invade the NW-SE ones like point X4 in Fig. 6 (Wadi Abu Qirayah). The E-W valleys also invade the N-S ones, as at point X5 in Fig. 6 (Wadi Al Kawalah) and X6 in Fig. 6 (Wadi Murayn). The Landsat images and field observation showed that the drainage modification and incision are due to active faulting (Fig. 9A, B). Some valleys show large meanders, such as Wadi Abu Dabbab, Wadi Dabr, Wadi Mubarak, and Wadi Abu Dabbab Al Abyad, among others.

The old drainage in the NW-SE and N-S directions was shifted, modified, pirated and/or abandoned by the E-W and NE-SW drainage lines (Fig. 9A, B and C). A typical example is the central part of Wadi Abu Dabbab. Even within the same direction of drainage lines, more than one generation can be recognized (Fig. 9C). Shoulder incision in drainage lines over the hanging wall of the faults 
166 A. Akawy

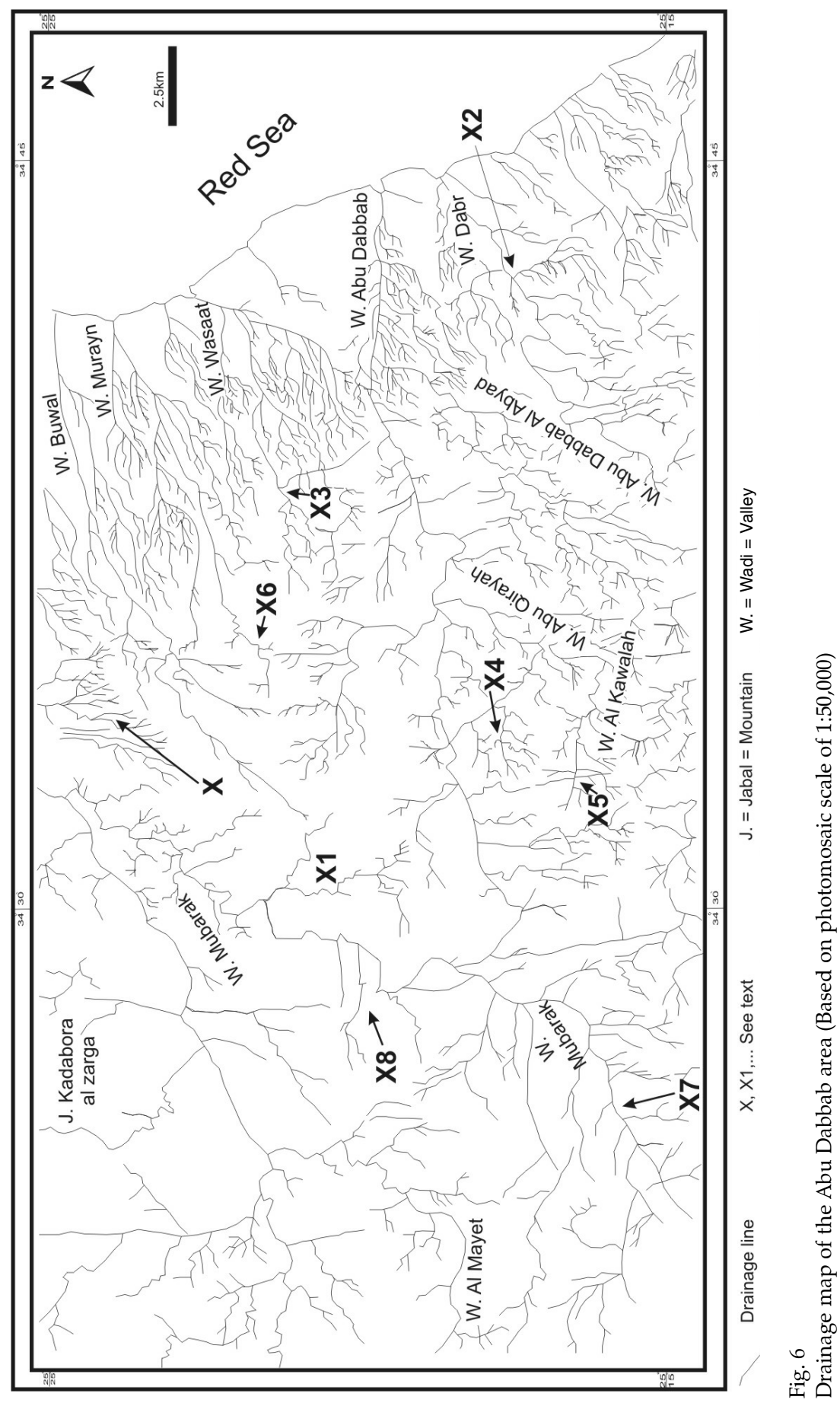

Central European Geology 51, 2008 


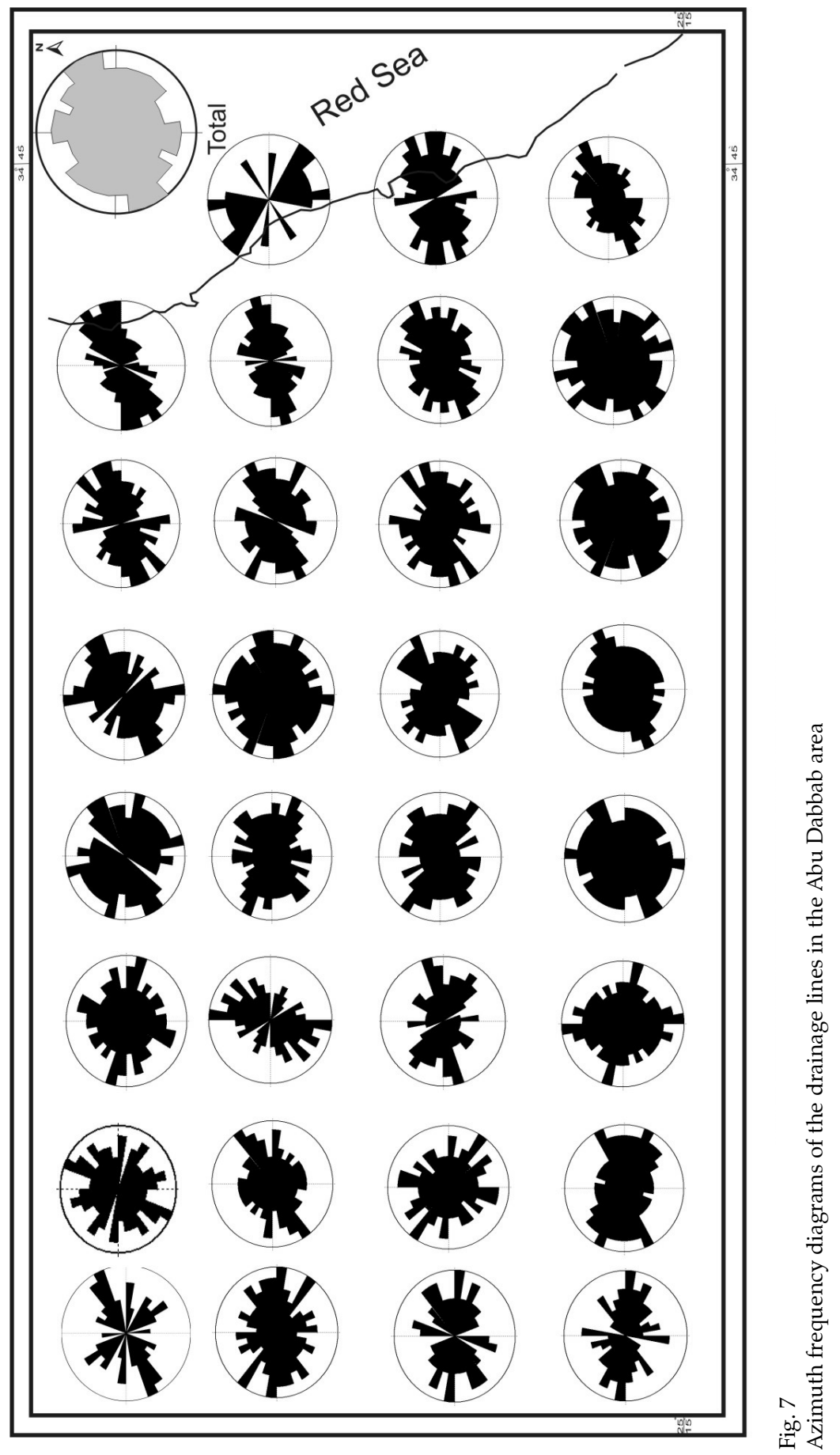

Central European Geology 51, 2008 
168 A. Akawy

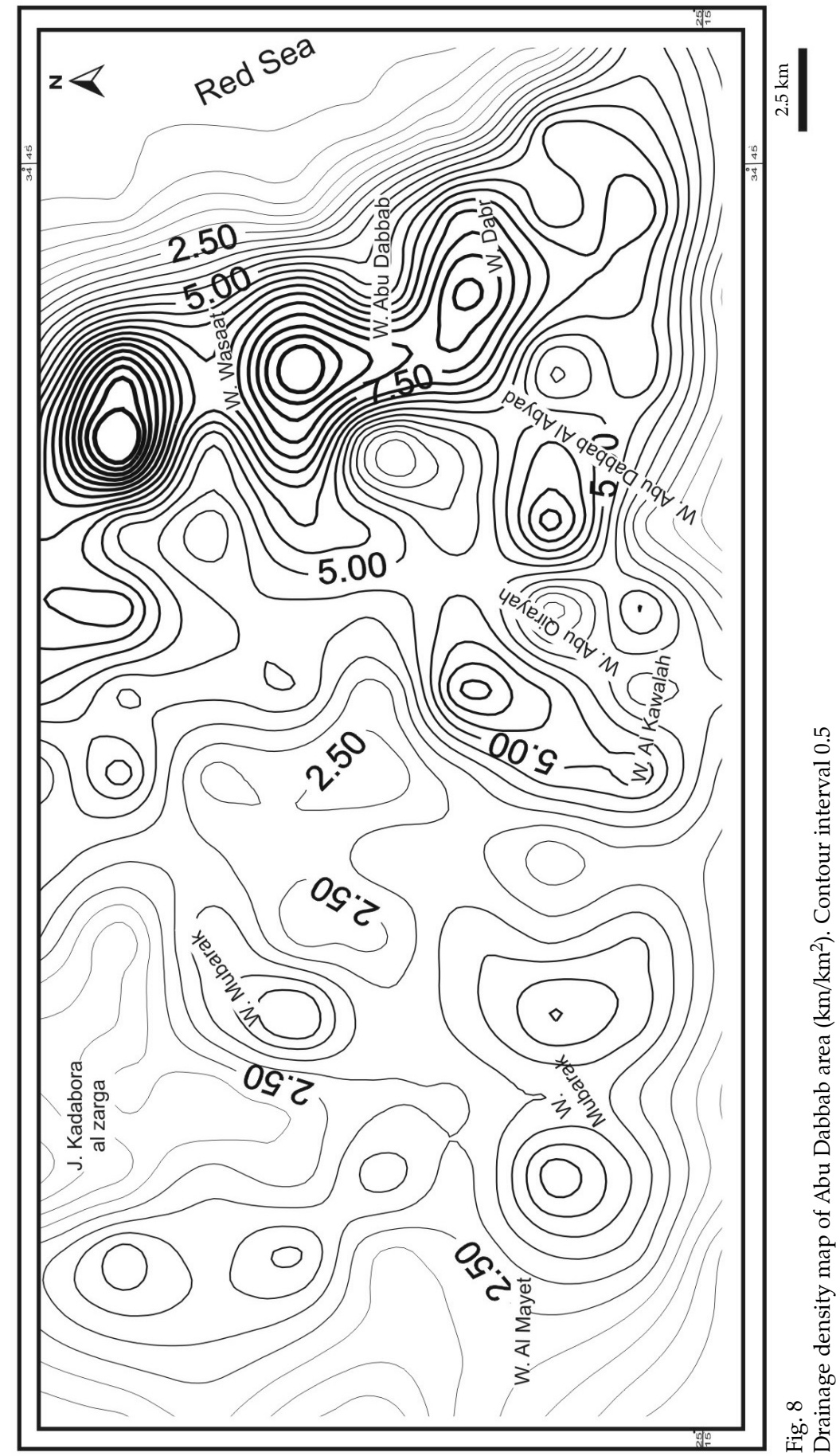



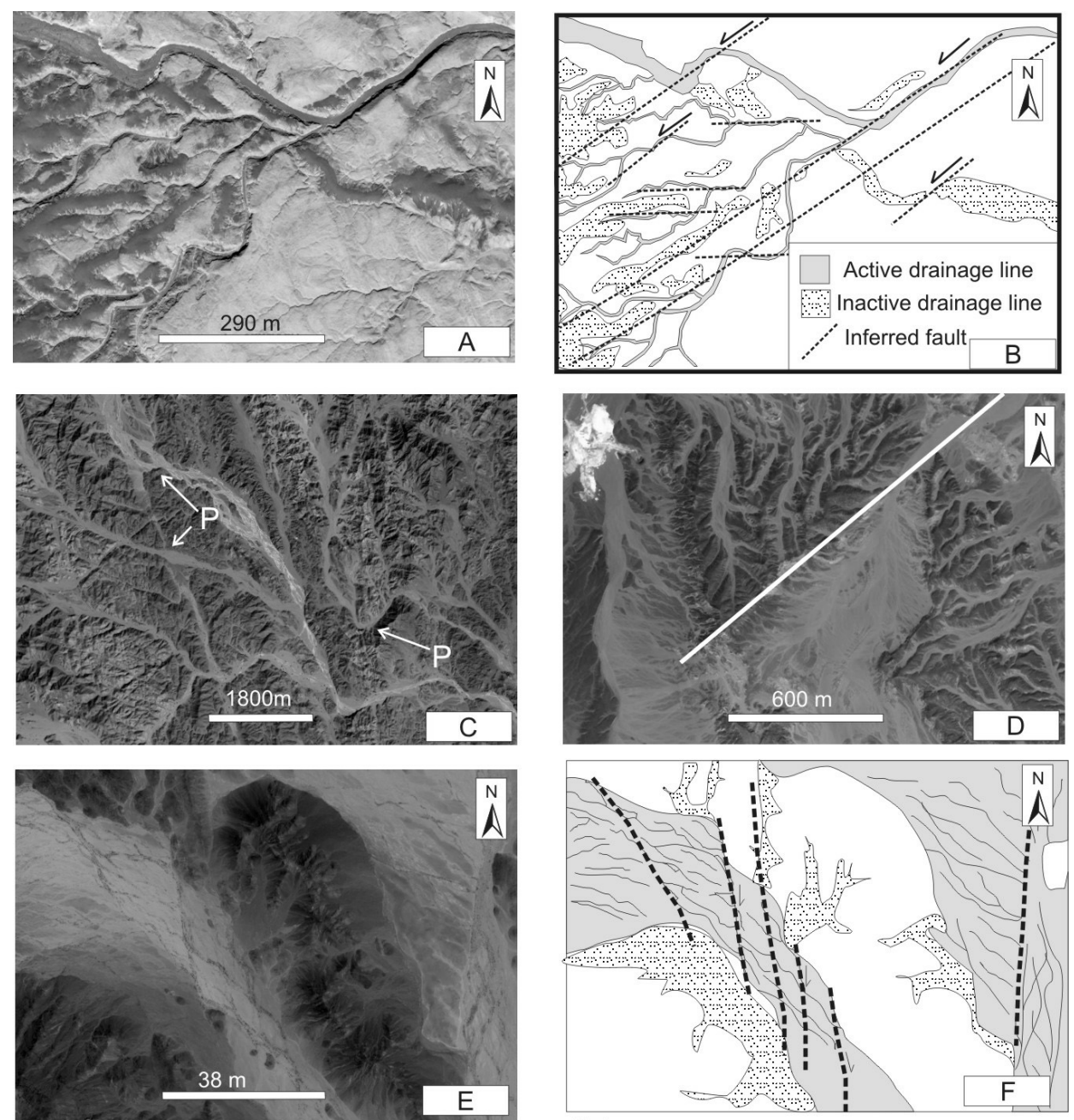

Active, braided drainage lines

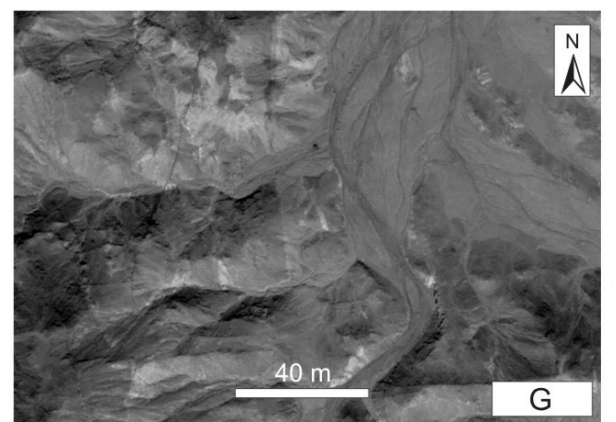

Fig. 9

Landsat images show the characters of the drainage pattern in the study area. A) Image shows active and inactive drainage lines; $\mathrm{B}$ ) Sketch based on A; C) Different orientations of structurally controlled drainage lines cross and pirate each other (point P); D) NE-SW fault scarp causes local water divide; E) Active rightlateral strike-slip faults affect recent braided drainage; F) Sketch based on E; G) Recent drainage incision and braiding 

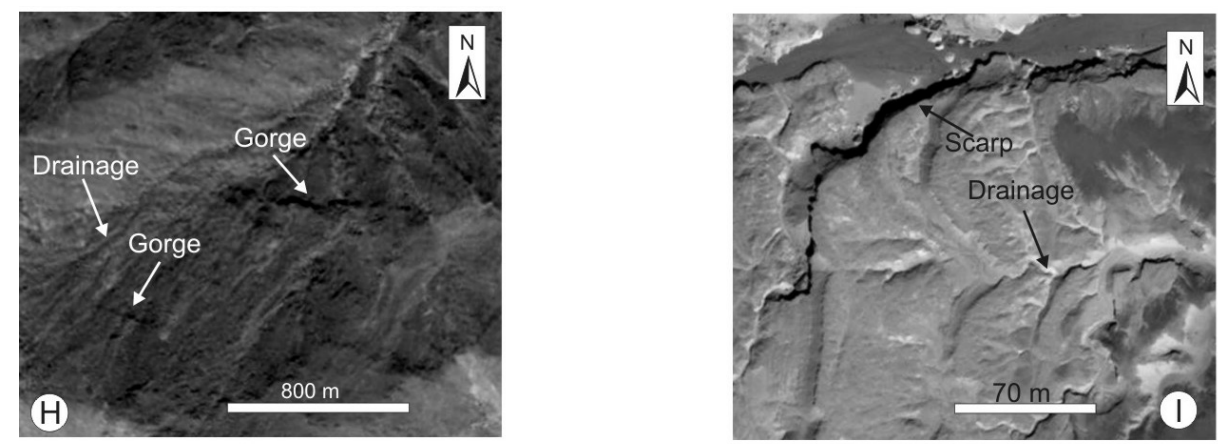

Fig. 9 cont.

H) Recent gorges cut drainage lines; I) Recent fault scarp stops drainage lines

and shifting in the flow direction toward the footwall are common. New valleys are formed over the active faults and fractures. Commonly, the NW-SE drainage is discontinuous and deflected toward the other active drainage lines.

There are variations in length, width and bed level of valleys. Long valleys (e.g. Wadi Abu Dabbab) run over a long distance $(40 \mathrm{~km})$ whereas other valleys only attain a half kilometer in length. Even within the same drainage set there is a wide variation in length. The valleys' width ranges from more than $300 \mathrm{~m}$ to less than $10 \mathrm{~m}$. From west to east there is a gradation in the bed stream level from high to low. The height of both valley sides is variable, particularly when a normal fault controls the valley course. The sharpness of the valley sides and their height relative to stream floor depend on the age of controlling faults on the one hand and rock resistance on the other. In the eastern part of the study area, due to softness of the sedimentary rocks there is no anomaly in longitudinal stream profile. Westward, in the Precambrian rocks, anomalous gradients are observed. Two main levels of stream beds can be discriminated; one in basement rocks and the other in the sedimentary rocks. For the majority of streams in the study area the base level ranges from 280 to $2 \mathrm{~m}$ asl. and each is characterized by saddles and shoulders.

Within the main broad valleys there are several sites of gravel accumulation (terraces) attaining 3 to $10 \mathrm{~m}$ height above the valley floor and which are generally linear in form. Local barriers and drainage divides are formed by the terraces. Braided streams are common (Fig. 9E, F and G) and contain gravel derived mainly from basement rocks, which decrease in size eastward. In the eastern parts of the area, vast domains are covered completely or partially by gravel and incised by active drainage (Fig. 2). Several generations of gravel-filled channels and superimposed drainage were recorded (Fig. 9C).

In the eastern part of the area there is conformity between the valley dimensions and drainage direction, i.e. the valley width increases from upstream to downstream. Westward this geometric relationship is not clear. 
On the aerial photographs there are linear and narrow gorges, presumably lowstand structures between parallel faults. These gorges cause reversal in drainage flow direction by stream capture. The reversal in drainage flow direction is a good indicator of active tectonics (Matmon et al. 1999). A good example for this feature is the area around Kadabora and the southern part of Wadi Mubarak (point X7 in Fig. 6). In the eastern part of the study area there are several successive alluvial fans of different topographic levels. These fans were developed on structural blocks which are bounded by normal faults with downthrow toward the NE.

\section{Drainage density}

There is a close relationship between drainage density and faults (Hou and Han 1997). Regardless of the outline of drainage basins, the entire study area has been divided into windows of $5 \times 5 \mathrm{~km}$ each to find this relationship. The drainage lines were digitized to measure their length and then contoured (Fig. 8). The spatial distribution of drainage density indicates that high-density belts characterize the eastern parts of the study area and reflect the presence of surface and concealed active faults (see Hou and Han 1997). The drainage intensity in this part reaches $10 \mathrm{~km} / \mathrm{km}^{2}$ or more. The rest of the study area also shows high density, attaining $4.5 \mathrm{~km} / \mathrm{km}^{2}$. Anomalous belts extend mainly in the $\mathrm{E}-\mathrm{W}$, NE-SW and N-S directions. The E-W anomaly belts appear in the extreme northern and southern parts of the study area. The NE-SW belts diagonally cross the area whereas the N-S belts characterize the area around the Kadabora faults. The NW-SE belts appear in the marginal area of the Red Sea. The E-W belts truncate the N-S ones, whereas the NE belts truncate all other belts. The drainage density anomalies are linear to ellipsoidal in form and connected or disconnected to each other. The anomaly belts can be 2 to $4 \mathrm{~km}$ wide and 10 to 40 $\mathrm{km}$ long. Some belts run straight whereas others are curved; the belts are either intermittent or continuous.

\section{Gaps and dry valleys}

The study of the aerial photographs and field observation indicated that there are several dry valleys and wind gaps (see Han et al. 2003; Pellegrini et al. 2003) on both sides of the active drainage lines. These gaps and dry valleys mainly resemble ancient NW-SE drainage lines that are abandoned and crossed by the active drainage (see also Fig. 9A and B). These gaps are characterized by gravel deposits and erosional features indicating that these are former water courses. 
Drainage and active faults

There are several criteria concerning the effect of active tectonics on valleys, such as cutting of recent terraces by structurally controlled drainage lines. The recent braiding and offset of the drainage near the Kadabora area and southern part of Wadi Mubarak indicate active faulting (Fig. 9E, F and G). Recent open gorges cutting drainage lines were detected on the Landsat images (Fig. 9H). Moreover, recent modification of drainage orientation by active faulting is well represented in the study area (Figs 9A, 9B and 9I). The capture of some drainage lines by others is a good indicator of active faulting.

Drainage and fault scarps

On the local and regional scales, fault scarps are the dominant controller of water divide orientation. Old and young NE-SW fault scarps are well developed in the study area and affect drainage orientation (Fig. 9D and I).

\section{Drainage and fault segmentation}

Some drainage lines cross the fault strikes without interruptions because the faults are segmented. This is the case in points X1, X3 in Fig. 6. The highs or lows between two N-S fault segments in Kadabora are due to the irregular strike or two separate segments (point X8 in Fig. 6). The same holds true for the NE-SW fault that controls Wadi Bowal and southern part of Wadi Mubarak, where there is uplift and drainage centrifuge (point X1 in Fig. 6). Wadi Abu Dabbab Al Abyad has two drainage courses; one toward the main NE-SW course and other parallel to the main course. This indicates that this valley is controlled by a fault zone rather than a single fault plane. These drainage lines are not completely affected by continuous $\mathrm{E}-\mathrm{W}$ faults, indicating segmentation of these faults.

\section{Wadi Abu Dabbab}

Since Wadi Abu Dabbab is the main wadi in the study area, it is studied in detail herein. The main course of Wadi Abu Dabbab runs in the E-W direction with local meandering and follows the NE-SW direction westward (Fig. 6). The southern inlets are longer, higher and more condensed than the northern ones and accordingly the boundaries are asymmetrical. At the entrance of Wadi Abu Dabbab, the southern tributaries are controlled by the N-S faults and flow off toward Wadi Abu Dabbab. This indicates that the fault or fault zone that controls the Abu Dabbab course $(E-W)$ is younger than the faults or fractures controlling these drainage lines. This is because the drainage is shifted toward the younger fractures. 


\section{Stress analysis of faults}

Paleo- and present-day stresses of faults were analyzed in Abu Dabbab area. This link was carried out to interpret the reactivation history of the faults in the context of the regional stress changes. The paleostress analysis is based on measurement of the fault striae and other shear sense indicators. The present-day stress analysis is based on direct stress distribution on: 1) recent structural features, 2) recent drainage modification and 3) seismic data.

\section{Paleostress analysis}

Several stations were selected in the field to measure slip data for the purpose of paleostress analysis. When possible, particularly in basement rocks, some shear sense indicators were used to determine the type of faults. The field stations cover nearly all parts of the study area. The data were analyzed using the "Tectonics FP" software by Franz Reiter and Peter Acs 1996-2002. The data input of this program include: 1) dip amount and direction of the fault plane, 2) plunge amount and direction of striae, 3) relative sense of movement of the hanging wall of the fault and 4) quality parameter representing confidence of the fault sense value. The confidence parameter was modified from Hardcastle (1989) and Sperner et al. (1993). The data were first separated manually into four orientations that are N-S, NE-SW, NW-SE and E-W (Figs 10 and 11). Based on the plunge amount and orientation of striae the faults in each trend were separated into three clusters that are normal, oblique and strike-slip. The normal, oblique and strike-slip faults are present in all orientations and their relative significance differs from one orientation to the other. The amount of fault plane dips and striae plunge cover a wide range (Fig. 10). The computation of the paleostress orientation is based on calculation of the compressive and extension dihedra for each fault plane (Angelier and Mechler 1977). The results of the paleostress analysis are shown in Table 3. Figure 12 shows the location of some field measurements and hypothetical nodal planes (beach balls) of the faults.

\section{Present-day stress analysis}

In addition to fault scarps the recent structural features include open and barren fissures, normal faults and strike-slip faults. Table 6 shows details of the inferred stresses of these features.

The examination of recent Landsat images and the field observations concluded that there is a good visible modification in orientation and/or width of some drainage lines. The narrower the valleys, the greater the modification. The effect of the NE-SW, E-W and N-S faults on the drainage lines exceeds that of the NW-SE faults. The effect of faults is not only a modification of the old drainage but also the development of new drainage on the newly formed and reactivated fault segments. Both extensional and strike-slip movements affect the drainage lines Table 6. 

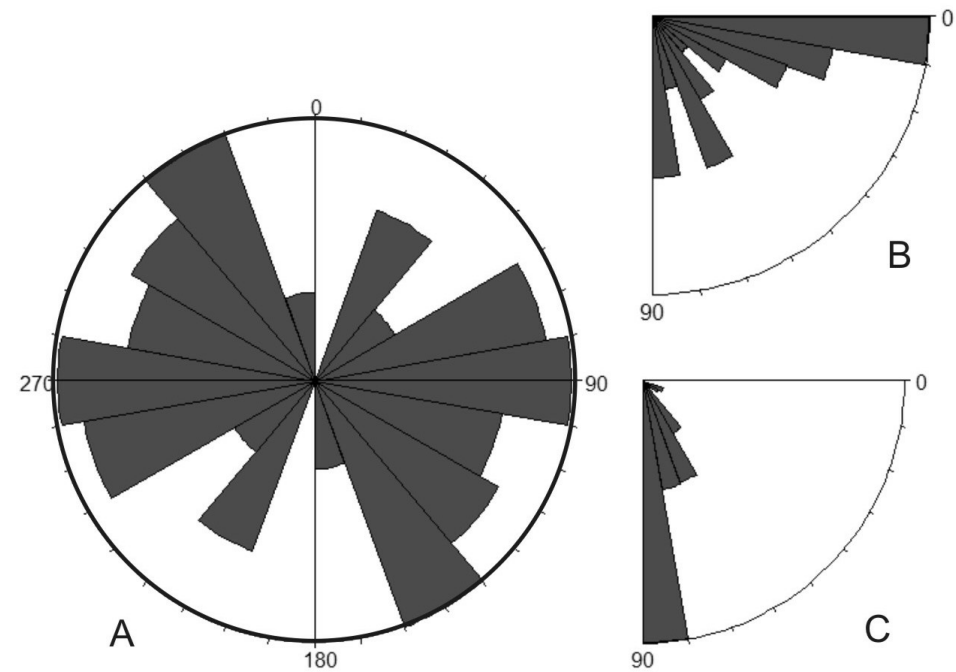

Fig. 10

Analysis of the measured faults. A) Azimuth frequency diagram of faults; B) Plot shows the plunge amount of striae; C) Plot shows the dip amount of fault planes

Table 3

Results of the paleostress analysis of faults

\begin{tabular}{|c|c|c|c|c|c|c|c|c|}
\hline \multirow[t]{3}{*}{ Faults } & \multirow[t]{3}{*}{ Type } & \multirow{3}{*}{ No. } & \multicolumn{6}{|c|}{ Paleostress axes } \\
\hline & & & \multicolumn{2}{|c|}{$\sigma 1$} & \multicolumn{2}{|c|}{$\sigma 2$} & \multicolumn{2}{|c|}{$\sigma 3$} \\
\hline & & & 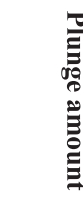 & 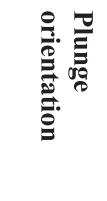 & 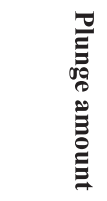 & 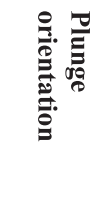 & 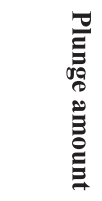 & 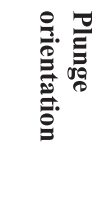 \\
\hline \multirow{3}{*}{$\mathrm{N}-\mathrm{S}$} & normal & 58 & 76 & 272 & 02 & 008 & 14 & 099 \\
\hline & oblique & 31 & 03 & 130 & 51 & 036 & 39 & 222 \\
\hline & Strike-slip & 59 & 07 & 317 & 83 & 112 & 03 & 227 \\
\hline \multirow{4}{*}{ NE-SW } & & & & & & & & \\
\hline & normal & 44 & 77 & 300 & 03 & 042 & 13 & 133 \\
\hline & oblique & 48 & 23 & 134 & 24 & 235 & 55 & 005 \\
\hline & Strike-slip & 23 & 01 & 103 & 86 & 209 & 04 & 013 \\
\hline \multirow{3}{*}{ NW-SE } & normal & 45 & 64 & 052 & 00 & 143 & 26 & 233 \\
\hline & oblique & 39 & 02 & 188 & 38 & 280 & 52 & 095 \\
\hline & Strike-slip & 66 & 06 & 001 & 76 & 244 & 12 & 093 \\
\hline \multirow{3}{*}{ E-W } & normal & 26 & 68 & 014 & 06 & 268 & 21 & 176 \\
\hline & oblique & 15 & 36 & 047 & 50 & 254 & 14 & 147 \\
\hline & Strike-slip & 37 & 20 & 236 & 55 & 357 & 27 & 135 \\
\hline
\end{tabular}




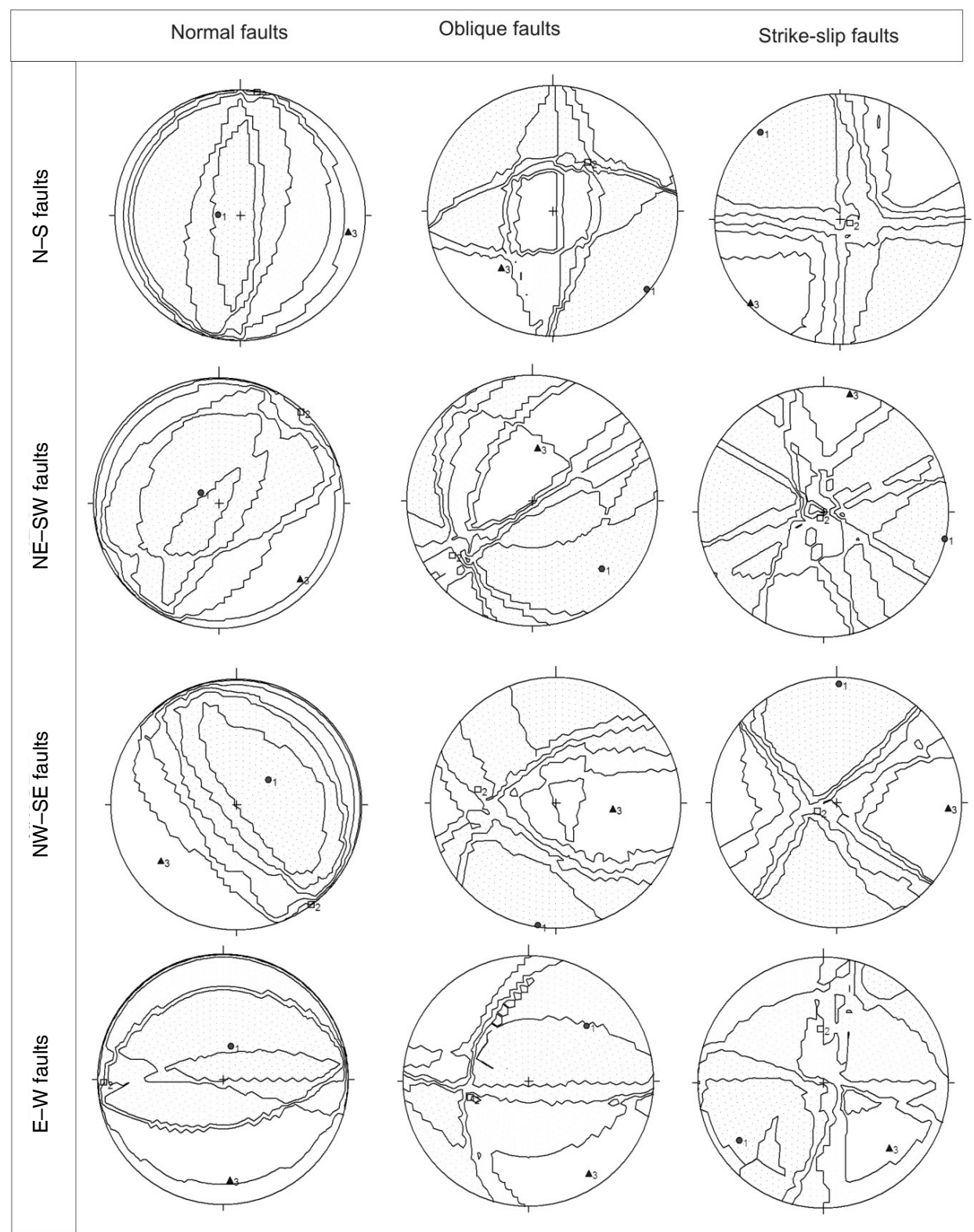

Fig. 11

Paleostress axes of the measured faults (lower hemisphere). 1, 2 and 3 are maximum, intermediate and minimum stress axes, respectively 


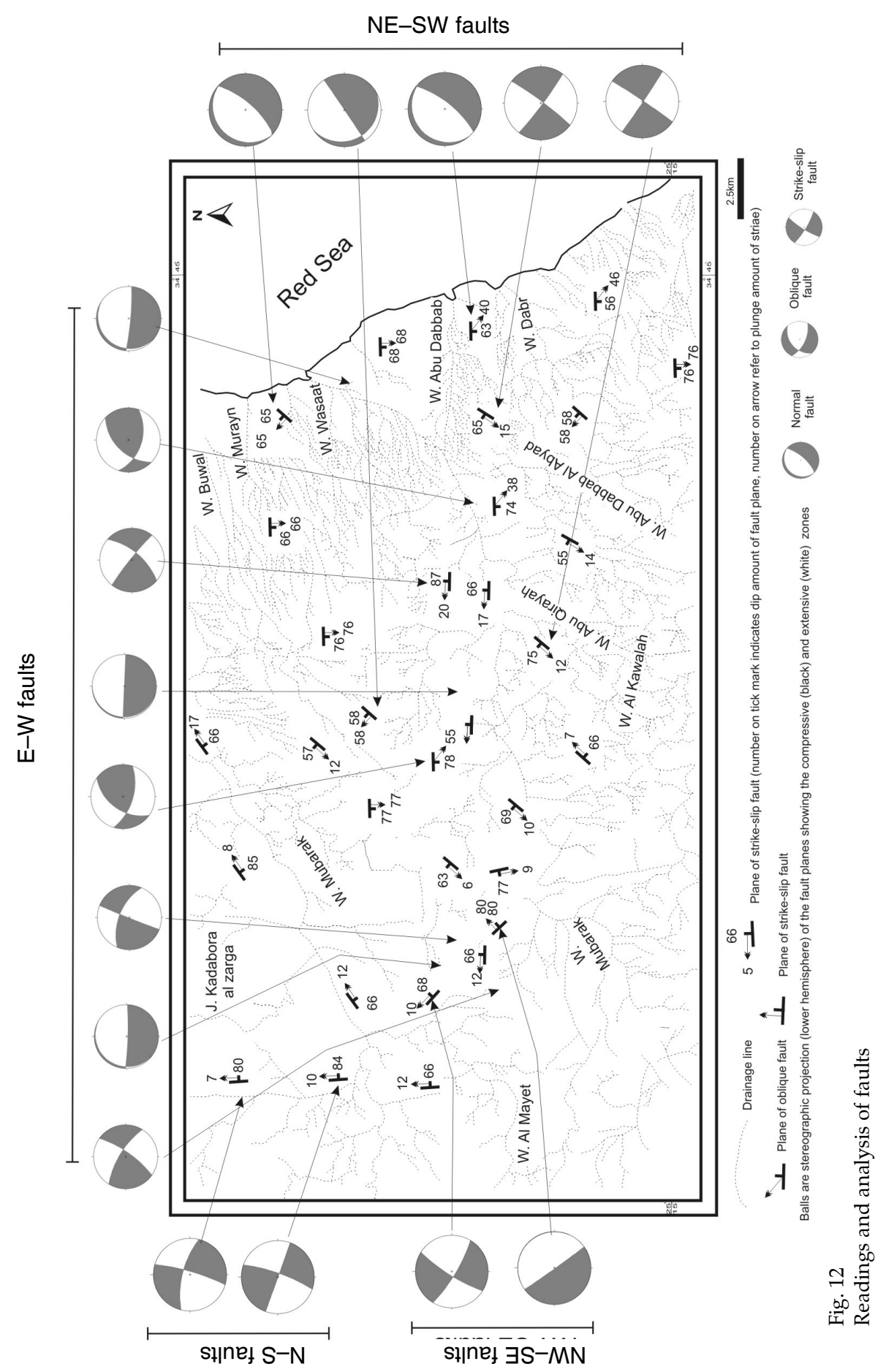

Central European Geology 51, 2008 
Table 4

Number of earthquakes per day (from 1st July 2004 to 20th August 2004) in Abu Dabbab area (after Mohamed 2005)

\begin{tabular}{|c|c|c|c|}
\hline Day & No. of earthquakes & Day & No. of earthquakes \\
\hline July, $1^{\text {st }} 2004$ & 108 & August, $9^{\text {th }} 2004$ & 18 \\
\hline July, $2^{\text {nd }} 2004$ & 86 & August, $10^{\text {th }} 2004$ & 18 \\
\hline July, $3^{\text {rd }} 2004$ & 38 & August, $11^{\text {th }} 2004$ & 28 \\
\hline July, $4^{\text {th }} 2004$ & 15 & August, $12^{\text {th }} 2004$ & 57 \\
\hline July, $5^{\text {th }} 2004$ & 27 & August, $13^{\text {th }} 2004$ & 94 \\
\hline August, $1^{\text {st }} 2004$ & 9 & August, $14^{\text {th }} 2004$ & 59 \\
\hline August, $2^{\text {nd }} 2004$ & 12 & August, $15^{\text {th }} 2004$ & 52 \\
\hline August, $3^{\text {rd }} 2004$ & 7 & August, $16^{\text {th }} 2004$ & 31 \\
\hline August, $4^{\text {th }} 2004$ & 16 & August, $17^{\text {th }} 2004$ & 10 \\
\hline August, $5^{\text {th }} 2004$ & 9 & August, $18^{\text {th }} 2004$ & 19 \\
\hline August, $6^{\text {th }} 2004$ & 25 & August, $19^{\text {th }} 2004$ & 25 \\
\hline August, $7^{\text {th }} 2004$ & 19 & August, $20^{\text {th }} 2004$ & \\
\hline August, $8^{\text {th }} 2004$ & 16 & & \\
\hline
\end{tabular}

Table 5

Types of faults in the Abu Dabbab area as inferred from the analysis of seismic activity (after Mohamed 2005)

\begin{tabular}{|c|c|l|}
\hline Strike & Dip amount & \multicolumn{1}{c|}{ Type } \\
\hline 53 & 66 & Almost pure strike-slip fault \\
\hline 95 & 43 & Reverse fault with some strike-slip component \\
\hline 264 & 71 & Reverse fault with some strike-slip component \\
\hline 311 & 43. & Reverse fault with some strike-slip component \\
\hline 317 & 31 & Reverse fault with some strike-slip component \\
\hline 311 & 41 & Reverse fault with some strike-slip component \\
\hline 311 & 43 & Reverse fault with a strike-slip component \\
\hline 14 & 55 & Normal fault with a strike-slip component \\
\hline 66 & 80 & Normal fault with a strike-slip component \\
\hline 304 & 57 & Strike-slip fault with a normal component \\
\hline 242 & 77 & Strike-slip fault with some reverse component \\
\hline 55 & 80 & Strike-slip fault with some reverse component \\
\hline & &
\end{tabular}

Because of the seismic activity of the Abu Dabbab area, a program of microearthquake monitoring, including ten telemetry stations, was established at the beginning of May 2004 (Mohamed 2005). Microearthquakes are those with a magnitude of less than 3 (Hagiwara 1964). During July and August 2004 a total of 860 microearthquakes was recorded (Tables 4 and 5). Mohamed (2005) concluded that the seismic activity is more or less concentrated and clustered along the active faults which include two main trends. The first belongs to a normal fault system which is more or less parallel to the Red Sea margin and the other set is a transverse fault system perpendicular to the Red Sea. Some reverse faults parallel to the Red Sea were inferred from this analysis. The analysis of focal depth of seismic events showed that these are upper crustal and range in depth from 4 to $17 \mathrm{~km}$. The seismic activity was concentrated at two depths, which are 5-8 and $10-13 \mathrm{~km}$. 
Table 6

Inferred and calculated present-day stresses in the Abu Dabbab area

\begin{tabular}{|c|c|c|c|}
\hline \multirow{2}{*}{ 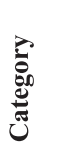 } & \multirow[b]{2}{*}{ Feature } & \multicolumn{2}{|c|}{ Inferred stress } \\
\hline & & Orientation & Type \\
\hline \multirow{12}{*}{ 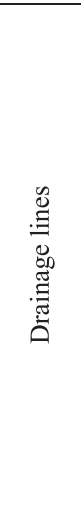 } & Offset by $\mathrm{N}-\mathrm{S}$ right-lateral strike-slip faults & NE-SW & Compressive \\
\hline & Offset by N-S left-lateral strike-slip faults & NW-SE & Compressive \\
\hline & $\begin{array}{l}\text { Development on neo-formed and/or reactivated } \mathrm{N}-\mathrm{S} \\
\text { extensional faults }\end{array}$ & $\mathrm{E}-\mathrm{W}$ & Extensive \\
\hline & Offset by E-W right-lateral strike-slip faults & NW-SE & Compressive \\
\hline & Offset by NE-SW right lateral strike-slip faults & $\mathrm{E}-\mathrm{W}$ & Compressive \\
\hline & Offset by NE-SW left lateral strike-slip faults & $\mathrm{N}-\mathrm{S}$ & Compressive \\
\hline & $\begin{array}{l}\text { Development on neo-formed and/or reactivated NE-SW } \\
\text { extensional faults }\end{array}$ & NW-SE & Extensive \\
\hline & Offset by WNW-ESE right lateral strike-slip faults & NNW-SSE & Compressive \\
\hline & Offset by NW-SE right lateral strike-slip faults & $\mathrm{N}-\mathrm{S}$ & Compressive \\
\hline & $\begin{array}{l}\text { Development on neo-formed and/or reactivated NW-SE } \\
\text { extensional faults }\end{array}$ & NE-SW & Extensive \\
\hline & Offset by E-W right lateral strike-slip faults & NW-SE & Compressive \\
\hline & $\begin{array}{l}\text { Development on neo-formed and/or reactivated E-W } \\
\text { extensional faults }\end{array}$ & $\mathrm{N}-\mathrm{S}$ & Extensive \\
\hline \multirow{5}{*}{ 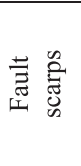 } & Characterize $\mathrm{N}-\mathrm{S}$ normal faults & $\mathrm{E}-\mathrm{W}$ & Extensive \\
\hline & Characterize NE-SW normal faults & NW-SE & Extensive \\
\hline & Characterize NW-SE normal faults & NE-SW & Extensive \\
\hline & Characterize E-W normal faults & $\mathrm{N}-\mathrm{S}$ & Extensive \\
\hline & Characterize $\mathrm{N}-\mathrm{S}$ right-lateral strike-slip faults & NW-SE & Compressive \\
\hline \multirow{6}{*}{ 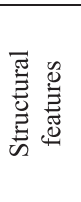 } & $\mathrm{N}-\mathrm{S}$ open and barren fissures & $\mathrm{E}-\mathrm{W}$ & Extensive \\
\hline & NE-SW open and barren fissures & NW-SE & Extensive \\
\hline & NW-SE open and barren fissures & NE-SW & Extensive \\
\hline & Recent NW-SE faults & NE-SW & Extensive \\
\hline & Recent E-W right lateral strike-slip faults & NW-SE & Compressive \\
\hline & Recent E-W normal faults & $\mathrm{N}-\mathrm{S}$ & Extensive \\
\hline \multirow{8}{*}{ 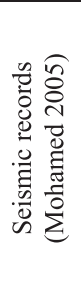 } & NNE-SSW normal fault with a strike-slip component & ESE-WNW & Extensive \\
\hline & NE-SW pure strike-slip fault & $\mathrm{N}-\mathrm{S}$ & Compressive \\
\hline & NE-SW strike-slip fault with some reverse component & $\mathrm{N}-\mathrm{S}$ & Compressive \\
\hline & NW-SE reverse fault with a strike-slip component & $\mathrm{N}-\mathrm{S}$ & Compressive \\
\hline & NNW-SSE strike-slip fault with a normal component & NNE-SSW & Compressive \\
\hline & ENE-WSW normal fault with a strike-slip component & NNW-SSE & Extensive \\
\hline & $\begin{array}{l}\text { ENE-WSW strike-slip fault with some reverse } \\
\text { component }\end{array}$ & NNW-SSE & Compressive \\
\hline & E-W reverse fault with some strike-slip component & $\mathrm{N}-\mathrm{S}$ & Compressive \\
\hline
\end{tabular}

Table 6 and Fig. 13 summarize the inferred present-day stress orientations of Abu Dabbab area. 


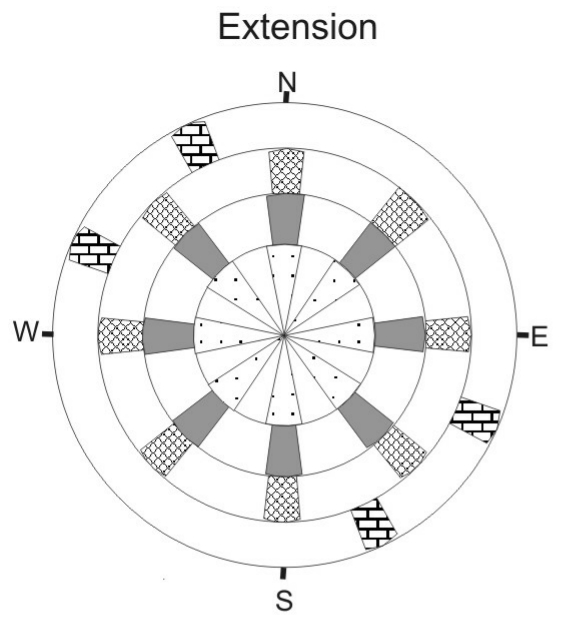

Extension (or compression) inferred - from recent drainage deflection

Extension (or compression) inferred from recent fault scarps

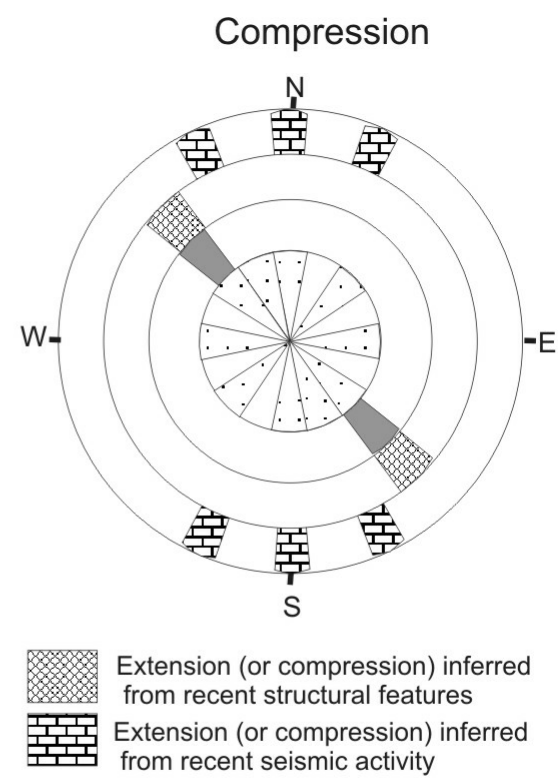

Fig. 13

Inferred present-day extensive and compressive stresses

\section{Discussion}

Based on the pattern of slip lineation on the fault planes, a complicated history of reactivation was inferred. In Quaternary sediments the reactivated faults are extensional. A few observations show hybrid and/or pure strike-slip faults, especially in the E-W and NE directions. All fault trends in the basement rocks show a tendency to change from pure strike-slip to extensional faults (Akawy 2003, 2005).

The N-S faults have been thoroughly discussed and interpreted in another contribution (Akawy 2007). This study concluded that these faults undergo strain partitioning in which strike-slip and normal fault domains appear. The western part of the Abu Dabbab area contains the famous N-S left-lateral strike-slip faults which are the Kadabora faults. In Quaternary sediments the N-S tectonic trend was recognized as normal faults, extensional fractures and strike-slip faults with very small lateral displacement. The hybrid nature of the N-S faults (strike-slip and normal) was also identified.

In the study area, the NE-SW faults dissect Quaternary sediments of varying nature. They are found as strike-slip faults (right- and left-lateral), normal faults and extensional fractures. The variability in nature indicates that this trend undergoes different types of local stresses in addition to the predominant regional stress. Meshref (1990) interpreted the NE-SW faults in the Red Sea area as conjugate of the NW-SE faults. 
The NW-SE tectonic trend was recorded in Quaternary sediments as normal faults and extensional fractures. Rare NW-SE strike-slip faults with $\mathrm{cm}$-scale lateral displacement were recorded in Quaternary sediments (see also Akawy 2005). This implies that the NW-SE tectonic trend presently undergoes extension due to the continuous opening of the Red Sea. The NW-SE faults relate to the Najd Fault System which is a series of left-lateral strike-slip faults extending from the Najd area (Saudi Arabia) into the Eastern Desert of Egypt (Stern 1985; Jarrige et al. 1986; Akawy 2002, 2003, 2005, 2007).

The E-W faults are considered the most active ones in the study area. The predominance of the strike-slip movement across this trend exceeds the extension.

During the Red Sea rifting, the E-W faults are considered to be accommodation zones between the tilted fault blocks (Cochran and Martinez 1988; Moustafa 1997). Dextral wrenching with transtension of the E-W faults was noted by Moustafa and Khalil (1994) and Moustafa and Abd-Allah (1992). El Gaby et al. (1988) named this trend as "Sheikh Salem trend" that relates to a Precambrian ENE to NE compressive stress. Bosworth and Strecker (1997) identified two sets of the E-W faults in the northern Red Sea. The older set consists of ENE-WSW right-lateral strike-slip faults and the younger of E-W normal faults. They assigned the older set to a NNE-SSW extension and the younger to a N-S extension. They added that the E-W faults predominate and run for long distances across the Eastern Desert, passing the Nile Valley, into the Western Desert. The E-W faults are particularly significant in the southern Eastern Desert. West of Lake Nasser this fault trend causes seismicity (Omar 2006).

The variation in steepness and height of the N-S fault scarps leads to the conclusion that they were formed due to recurrent faulting. This conclusion appears logical when compared with the tectonic history of the N-S faults which comprises different ages and types of movement. The scattering of the NE-SW fault scarps suggests that these originated through successive reactivation events, separated by short quiescence periods. The difference in morphology of the E-W Quaternary fault scarps suggests that these have different ages, which in turn indicates continuous reactivation. Also, the variation in slope angle and/or height in the same cluster presumably indicate step faulting. The scattering of the NW-SE fault scarps suggests that they have both step and composite nature. The presence of scarps with rounded apex in the country rocks and presently show displacement of Quaternary sediments confirms the latter conclusion.

When considering the effect of active faults on drainage pattern, drain direction rather valley direction should be considered (see Matmon et al. 1999). At present the drainage flows off toward the Red Sea basin in the E-W to NE direction. The E-W and NE-SW faults and fractures are the main controllers of drainage. Dip of Neogene sediments share in guiding drainage lines in this directions. Some lines drain toward the NW and SE due to local water divides formed by the NE-SW faults. Particularly in the western parts of the area the N-S faults guide some of the drainage lines. Gorges formed by recent $\mathrm{N}-\mathrm{S}$ faults cause 
reversal in drainage flow direction from ENE to WSW. Also, near the Red Sea shoreline tilting of some faulted blocks locally affects drainage orientation. The field inspection and examination of aerial photographs and Landsat images showed that the old drainage lines were running in the NW-SE direction and the presently active ones are running in the N-S, NE-SW and E-W directions. This certainly reflects the activity of the controlling faults. The capture of old drainage, deep incision of the recent one, offset of drainage in all orientation and reversal in drainage flow direction are the main drainage modifications.

There is a proportional relationship between drainage density and fault activity because the concealed fault zones could provide a passage for underground water, small lakes and rivers (Hou and Han 1997; Han et al. 2003). The eastern part of the study area which is characterized by high drainage density, probably undergoes subsidence relative to the western part that undergoes uplift. This relative movement implies a vertical movement across the main NW-SE faults. Moreover, the anomaly in drainage density that is associated with active faults increases near the Red Sea shoreline. This indicates that there is a close relationship between the present-day Red Sea tectonics and the activity of these faults. In some localities there is a good match between the high drainage density belts and the field indicators of active faulting; in other localities this relationship is not clear. This poor relationship is probably due to the inability to detect these faults in the field and/or the change in tectonic conditions. The latter means that the old active faults that caused high drainage density became inactive in present time. Due to the predominance of the active fissures in the eastern parts, the sharpness in the density belts is greater than that in the western part. The intermittent high drainage belts indicate that they are underlined by newly established fault segments that combine short fissures and coalesce to give a continuous fault (see Schweig and Ellis 1994). The drainage bifurcation is higher in the eastern part of the study area than in the western one, indicating that intense fracturing controls the drainage.

The asymmetry and complexity of drainage basins in the study area as indicated by wide variation in length, density and orientation of tributaries on both sides indicate non-coeval drainage generation on both sides. A good example is the asymmetry of the entrance of Wadi Abu Dabbab which is due to block tilting toward the E and ENE.

There is a mutual relationship in activity between the N-S and E-W faults, and no clear age arrangement can be inferred. The southern tributaries of Wadi Abu Dabbab are controlled by the N-S faults and flowing off toward the north, implying that the faults that control Wadi Abu Dabbab (E-W faults) are younger than the N-S ones. On the other hand, the northern inlets of Wadi Abu Dabbab are orientated in the N-S direction and narrow northward, indicating that the ancient $\mathrm{N}-\mathrm{S}$ faults were re-opened as normal faults by the strike-slip movement along the $\mathrm{E}-\mathrm{W}$ faults. The opening decreases northward. In some localities there is capture of the E-W streams by the N-S ones, indicating that the latter are younger. Westward in the study area the $\mathrm{N}-\mathrm{S}$ faults show strike-slip nature (see 
Akawy 2007). On the map scale the relative offset of the different fault orientations by others is not clear, due to the small magnitude of this displacement. In the field this relationship is clear.

The drainage density map, aerial photographs, Landsat images and field observations indicate that the fault segmentation phenomenon is common for all fault trends. This also indicates that the faults are still growing and coalesce. The observations also concluded that not all fault segments are active to the same degree, and that there are inactive ones. Within the same drainage pattern the continuation of some lines and stopping of others confirm the fault segmentation. Fault segmentation was also reported in other studies such as those of Naylor et al. (1986), Sylvester (1988) and Booth-Rea et al. (2004).

The present study was carried out in the summer of 2006, two years after the seismic records were acquired. Based on the seismic analysis of the area the faults are upper crustal features and do not continue below. The presence of recent reverse faults in the NW-SE direction is a puzzle because presently this trend is extensive. Mohamed (2005) referred these reverse faults to some deep magmatic activities and fluid overpressure during serpentinite dehydration. Akawy (1993) recorded NW-SE striking reverse faults and folds in the Red Sea marginal area and explained them as resulting from a space problem during basinward tilting of the blocks. The seismic study (Mohamed 2005) concluded that the seismic activity in the Abu Dabbab area is concentrated along two active fault sets, namely normal faults (parallel to the Red Sea) and transverse faults (perpendicular to the Red Sea). The seimicity is concentrated along the intersection between the two fault sets. In other areas in the world seismic activity also occurs in the intersection between faults (Talwani 1988; Mohamed 2005). In the Abu Dabbab area, the brittle/ductile transition is shallow (9-10 km), implying that an anomalous mantle or magma chamber can exist at this depth (Hoseny et al. 1996; Mohamed 2005). The present field study concluded that the $\mathrm{N}-\mathrm{S}$ and E-W faults are the more active than other trends. This does not conflict with the seismic studies because both agree on the active fault trends, differing only in the magnitude of the activity.

The drainage that develops on the $\mathrm{E}-\mathrm{W}$ faults appears to increase its length westwards by running on growing faults. Since the faults increase their length during repeated earthquakes (Jackson and Leeder 1994), the long faults in the study area were formed during long period of seismic activity. As stated previously some faults in the study area are segmented, and then the faults increase their length by coalescing of neighboring segments by local earthquakes (see also Gillespie et al. 1992; Davis et al. 2005). The correlation between the paleostresses and the present-day ones (Tables 3 and 6) shows that there is a change in tectonic conditions and stress states. The inferred present-day stress (Fig. 13) shows more or less multidirectional extension and N-S compression. The compression is due to the $\mathrm{N}$ to $\mathrm{NW}$-ward drifting of the African plate. The extension (limited and regional) leads to reactivation and/or neoformation of different fault trends in the study area (Fig. 14). This model is similar to that of 
Arkin (1989) for the Dead Sea-Jordan rift valley. The controversial sense of movement along the strike-slip faults is due to the difference in orientation of the faults relative to the mean extension. The NE-SW extension across the Red Sea and the $\mathrm{N}$ to NW drift of Africa toward the European plate are the main causes of the present stresses.

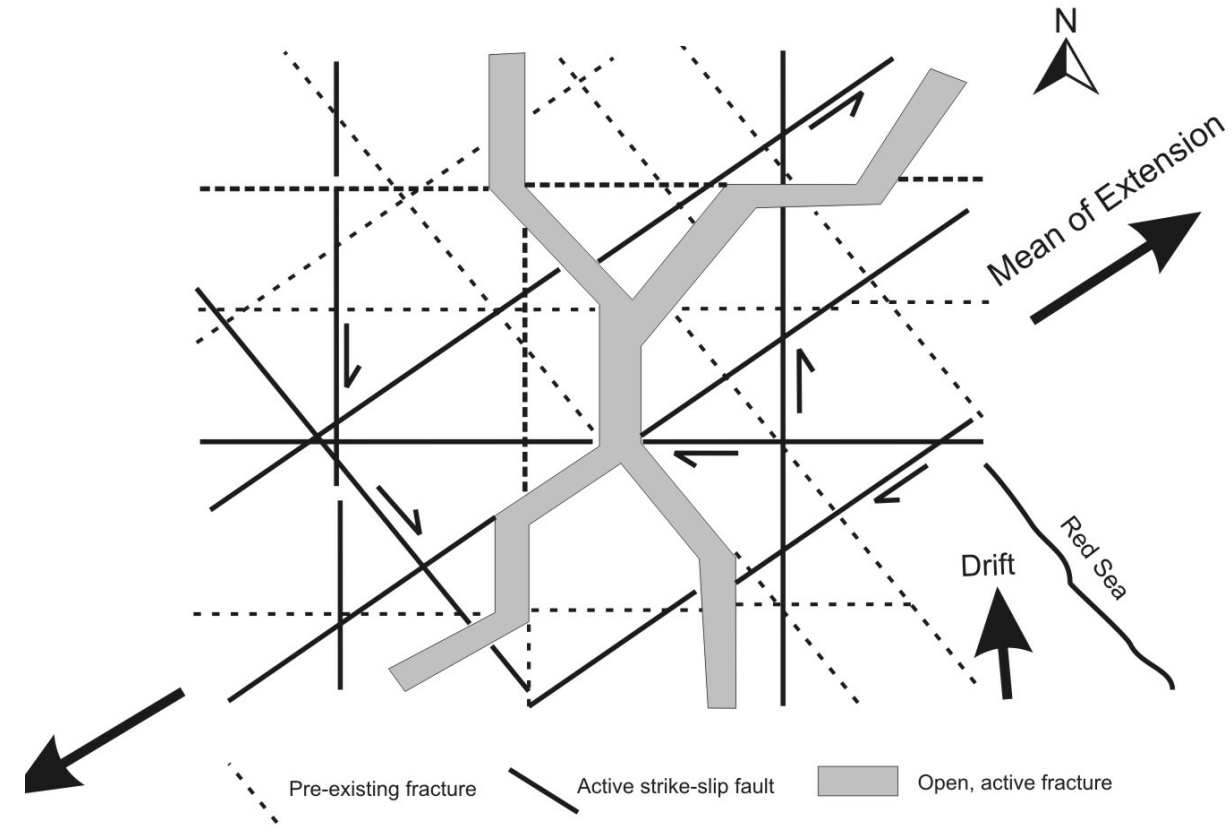

Fig. 14

Interpretation of the active faults and fractures in the Abu Dabbab area

\section{Conclusion}

The N-S, NE-SW, NW-SE and E-W fault trends have a complicated history of initiation and reactivation in the basement rocks, Neogene cover and Quaternary sediments in the Abu Dabbab area. Recent fault scarps with varying steepness and height have been recorded along these fault trends. The N-S fault scarps are formed during recurrent faulting whereas the NE-SW scarps are formed by successive reactivation, with short quiescence periods in between. The E-W scarps are formed by continuous reactivation. The NW-SE scarps are of both step and composite nature. The drainage lines are generally structurally controlled. The main water divide runs along the NW-SE trend and the local water divides are controlled by the NE-SW faults. The active faults cause some drainage modification like capture of old drainage, deep incision of the recent one, offset of drainage in all orientations and reversal in drainage flow direction. Several anomalies of drainage density in different orientations reflect concealed and active fault zones. Some drainage anomalies are disconnected suggesting fault 
segmentation. The degree of activity differs from one segment to the other. The faults grow by coalescing of neighboring segments through local earthquakes. There is a poor matching between the paleostresses and the present-day ones, attributed to the change in the tectonic conditions. The present-day NE-SW extension across the Red Sea combines with local multidirectional one, by reactivation and neo-formation of all faults of different types and directions.

\section{Acknowledgements}

The author thanks Prof. Dr. Moustaf Youssef (Assiut University), Prof. Dr. Adel Sehim (Cairo University), Dr. Balazs Szekely (Vienna University of Technology), Dr. Arpad Magyari (Budapest University) and Dr. Basem Zoheir (Banha University) for revision and enhancing the manuscript. Many thanks to Dr. F. Reiter and Dr. P. Acs (Innsbruck University), for the availability of the Tectonics FP software via internet.

\section{References}

Akawy, A. 1993: Structural studies on the area north of Qusier, Red Sea, Egypt. - Unpubl. M.Sc. thesis NW-SE Assiut University, (Egypt). 206 p.

Akawy, A. 2002: Structural geomorphology and neotectonics of the Qina - Safaja district, Egypt. N.Jb. Geol. Palaont. Abh. 226, pp. 95-130.

Akawy, A. 2003: Fault characterization and paleostress analysis in the Precambrian rocks west of the Meatiq Dome, Central Eastern Desert, Egypt. - N. Jb. Geol. Palaont., Abh. 228, pp. 1-35.

Akawy, A. 2005: Tectonic impacts on drainage systems and topography from Precambrian to Recent in the Central Eastern Desert of Egypt: a model from the area south of Umm Gheig. - N. Jb. Geol. Palaont., Abh. 235, pp. 235-264.

Akawy, A. 2007: Characters and strain partitioning of the N-S striking faults and associated structures in the Eastern Desert of Egypt. - Neues Jahrbuch für Geologie und Paläontologie, Abhandlungen, 246, pp. 145-171.

Akawy, A., G. Kamal El Din 2006: Middle Eocene to Recent tectonics in the Qina area, Upper Egypt. - N. Jb. Geol. Palaont., Abh. 240, pp. 19-51.

Akkad, S.E., A. Dardir 1966: Geology and phosphate deposits of Wassif-Safaga area. - Pap. geol. Surv. Egypt 36, 55 p.

Angelier, J., P. Mechler. 1977: Sur une méthode graphique de recherche des contraintes principales également utilisable en tectonique et en séismologie: la methode des diédres droits. - Bull. Soc. Géol. France, 19, pp. 1309-1318.

Arkin, Y. 1989: Large-scale tensional features along the Dead Sea-Jordan Rift Valley. Tectonophysics, 165, pp. 143-154.

Avouac, J.P., G. Peltzer 1993: Active tectonics in southern Xinjian, China: Analysis of terrace riser and normal fault scarp degradation along the Hotan-Qira Fault System. - J. Geophys. Res., 98, pp. 21773-21807.

Bayasgalan, A., J. Jackson, J.F. Ritz, S. Carretier 1999a: Field examples of strike-slip fault terminations in Mongolia and their tectonic significance. - Tectonics, 18, pp. 394-411.

Bayasgalan, A., J. Jackson, J.F. Ritz, S. Carretier 1999b: "Forebergs", flower structures, and the development of large intracontinental strike-slip faults: the Gurvan Bogd system in Mongolia. - J. Struct. Geol., 21, pp. 1285-1302.

Beneduce, P., V. Festa, R. Francioso, M. Schiattarella, M. Tropeano 2004: Conflicting drainage patterns in the Matera Horst area, southern Italy. - Physics and Geochemistry of the Earth, 29, pp. 717-724. 
Bishop, P. 1995: Drainage rearrangement by river capture, beheading and diversion. - Progress in Physical Geography, 19, pp. 449-473.

Booth-Rea, G., J.M. Azanon, A. Azor 2004: Influence of strike-slip fault segmentation on drainage evolution and topography. A case study: the Palomares Fault Zone (southeastern Betics, Spain). - J. Struct. Geol., 26, pp. 1615-1632.

Bosworth, W., M. Strecker 1997: Stress field changes in the Afro-Arabian rift systems during the Miocene to Recent period. - Tectonophysics, 278, pp. 47-62.

Carretier, S., J.F. Ritz, J. Jackson, A. Bayasgalan 2002: Morphological dating of cumulative reverse fault scarps: examples from the Gurvan Bogd fault system, Mongolia. - Geophys. J. Int., 148, pp. 256-277.

Cochran, J.R., F. Martinez 1988: Evidence from the Northern Red Sea on the transition from continental to oceanic rifting. - Tectonophysics, 153, pp. 25-54.

Cotton, C.A. 1942: Geomorphology. - 3rd ed., Whitcombe and Tombs Ltd, Christchurch, New Zealand.

Davis, K., D.W. Burbank, D. Fisher, S. Wallace, D. Nobes 2005: Thrust-fault growth and segment linkage in the active Ostler fault zone, New Zealand. - J. Struct. Geol., 27, pp. 1528-1546.

Dunmont, J.F., E. Santana, W. Vilema 2005: Morphologic evidence of active motion of the Zambapala Fault, Gulf of Guayaquil (Ecuador). - Geomorphology, 65, pp. 223-240.

El Gaby, S., F. List, R. Tehrani 1988: Geology, evolution and metallogenesis of the Pan-African belt in Egypt. - In: El Gaby, S., R.O. Greiling (Eds.): The Pan-African belt of Northeast Africa and adjacent areas. Braunschweig (Vieweg) pp. 17-68.

El Haddad, A.A. 1984: Sedimentological and geological studies on the Neogene sediments of the Egyptian part of the Red Sea. - Unpubl. Ph. D. thesis (Assiut University, Egypt). 270 p.

El Kazzaz, Y.A. 1999: Active faulting along Qena-Safaja road, Eastern Desert, Egypt. - Proc. 1st Int. Conf. Geology Africa, Nov. 99, Assiut, Egypt 2, pp. 285-400.

Enzel, Y, R. Amit, N. Porat, E. Zilberman, B. Harrison 1996: Estimating the ages of fault scarps in the Arava, Israel. - Tectonophysics, 253, pp. 305-317.

Geological Survey of Egypt 1979: Geological map of Aswan, sheet NG-36.

Gillespie, P.A., J.J. Walsh, J. Watterson 1992: Limitations of dimension and displacement data from single faults and the consequences for data analysis and interpretation. - J. Struct. Geol., 14, pp. $1157-1172$.

Ginat, H., Y. Enzel, Y. Avni 1998: Translocated Plio-Pleistocene drainage systems along the Arava fault of the Dead Sea Transform. - Tectonophysics, 284, pp. 151-160.

Hagiwara, T. 1964: Brief description of the project proposed by the earthquake prediction research group of Japan. - Proc. U.S. Japan Conf. Res. Rela. Earthquake Prediction Probl., pp. 10-12.

Han, Z., L.Wu, Y. Ran, Y. Ye 2003: The concealed active tectonics and their characteristics as revealed by drainage density in the North China plain (NCP). - J. Asian Earth. Sc., 21, pp. 989-998.

Hardcastle, K.C. 1989: Possible paleostress tensor configurations derived from strike-slip data in Eastern Vermont and Western New Hampshire. - Tectonics, 8, pp. 265-284

Hoseny, M., I. Marzouk, S.M. El Hady 1996: The relation between heat flow, depth of seismicity and crustal structure for Abu Dabbab region, Eastern Desert, Egypt. - Bull. of National Institute of Astronomy and Geophysiscs, B, pp. 18-28.

Hou, J., M. Han 1997: A morphometric method to determine neotectonic activity of the Weihe basin in Northwestern China. - Episodes, 20, pp. 95-99.

Jackson, J., M.R. Leeder 1994: Drainage systems and the development of normal faults: an example from Pleasant Valley, Nevada. - J. Struct. Geol., 16, pp. 1041-1059.

Jarrige, J.J., D. Ott, P. Estevou, P.F. Burollet, J.C. Icart, C. Montenat, P. Prat, J.P. Richert, P. Srhans, J. Thiriet 1986: Inherited discontinuities and Neogene structure: the Gulf of Suez and the northwestern edge of the Red Sea. - Phil. Trans. R. Soc. London, Ser. A. 317, pp. 129-139.

Leeder, M., J.A. Jackson 1993: The interaction between normal faulting and drainage in active extensional basins, with examples from the western United States and central Greece. - Basin Res., 5, pp. 79-102.

Mather, A.E. 2000: Adjustment of a drainage network to capture induced base-level change: an example from the Sorbas Basin, SE Spain. - Geomorphology, 34, pp. 271-289. 
Matmon, A., Y. Enzel, E. Ziberman, A. Heimann 1999: Late Pliocene and Pleistocene reversal of drainage systems in northern Israel: tectonic implications. - Geomorphology, 28, pp. 43-59.

Mayer, L. 1984: Dating Quaternary fault scarps formed in alluvium using morphologic parameters. - Quaternary Research, 22, pp. 300-313.

Mayer, L., K.R.Vincent 1999: Active tectonics of the Loreto area, Baja California Sur, Mexico. Tectonophysics, 27, pp. 243-255.

Meshref, W. 1990: Tectonic framework. - In: Said, R. (Ed.): The Geology of Egypt. Rotterdam (Balkema) pp. 113-155.

Mohamed, G.A. 2005: A detailed microearthquakes study at Abu Dabbab area, Eastern Desert, Egypt. - Unpublished M.Sc. (South Valley University, Egypt), 142 p.

Moustafa, A.R. 1997: Controls on the development and evolution of transfer zones: the influence of basement structure and sedimentary thickness in the Suez rift and Red Sea. - J. Struct. Geol., 19, pp. 755-768.

Moustafa, A.R., A.M. Abd-Allah 1992: Transfer zones with en echelon faulting at the northern end of the Suez rift. - Tectonics, 11, pp. 499-506.

Moustafa, A.R., M.H. Khalil 1994: Rejuvenation of the eastern Mediterranean passive continental margin in northern and central Sinai: new data from the Themed Fault. - Geol. Mag., 131, pp. 435-448.

Nash, D.B. 1980: Morphological dating of degraded normal fault scarps. - J. Geology, 88, pp. 353-360.

National Stratigraphic Subcommittee of Geological Sciences of Egypt 1974: Miocene rock stratigraphy of Egypt. - J. Geol. Soc. Egypt, 18, 69 p.

Naylor, M.A., G. Mandl, C.H.K. Sijpesteijn 1986: Fault geometries in basement-induced wrench faulting under different initial stress states. - J. Struct. Geol., 8, pp. 737-752.

Ollier, C. 1981: Tectonics and landforms. - Longman, New York, 324 p.

Omar, K.A. 2006: Prediction of the strong ground motions due to large earthquakes using Green's function at important national structures in Aswan, Egypt. - Unpubl. M.Sc. thesis (South Valley University, Egypt), 120 p.

Pellegrini, L., P. Boni, A. Carton 2003: Hydrographic evolution in relation to neotectonics aided by data processing and assessment: some examples from the Northern Apennines (Italy). Quaternary International, 101, pp. 211-217.

Reiter, F, P. Acs 1996-2002: Tectonics FP: Computer Software for Structural Geology. - Institut für Geologie und Paläontologie, Universität Innsbruck. Available via internet at http://go.to/TectonicsFP.

Schweig, E.S., M.A. Ellis 1994: Reconciling short recurrence intervals with minor deformation in the New Madrid seismic zone. - Science, 264, pp. 1306-1311.

Sperner, B., T. Ott, L. Ratschbacher 1993: Fault-striae analysis: a turbo pascal program package for graphical presentation and reduced stress-tensor calculation. - Computers and Geosciences, 19, pp. 1361-1388.

Stern, R.J. 1985: The Najd Fault System, Saudi Arabia and Egypt: a Late Precambrian rift-related transform system? -Tectonics, 4, pp. 497-511.

Sterr, H. 1985: Rates of change and degradation of hillslopes formed in unconsolidated materials: a morphometric approach to date Quaternary fault scarps in Western Utah; USA. - Z. Geomorph., N.F. 29, pp. 315-333.

Sylvester, A.G. 1988: Strike-slip faults. - Geol. Soc. Am. Bull., 100, pp. 1666-1703.

Talwani, P. 1988: The intersection model of intraplate earthquakes. - Seismo Res. Lett., 59, pp. 305-310.

Walker, R., J. Jackson 2002: Offset and evolution of the Gowk fault, S.E. Iran: a major intracontinental strike-slip system. - J. Struct. Geol., 24, pp. 1677-1698. 